\title{
Pengaruh Sebaran Konsentrasi Klorofil-a Berdasarkan Citra Satelit terhadap Hasil Tangkapan Ikan Tongkol (Euthynnus sp) Di Perairan Selat Bali
}

\author{
I Made Satya Prayoga ${ }^{\text {a* }}$, I Dewa Nyoman Nurweda Putra a, \\ I Gusti Ngurah Putra Dirgayusa ${ }^{a}$ \\ a Program Studi Ilmu Kelautan, Fakultas Kelautan dan Perikanan, Universitas Udayana, Kampus Bukit Jimbaran, Bali 80361, Indonesia \\ * Penulis koresponden. Tel.: +6281-246-992-088 \\ Alamat e-mail: satyaprayoga93@gmail.com
}

Diterima (received) 30 November 2016; disetujui (accepted) 5 Februari 2017; tersedia secara online (available online) 6 Februari 2017

\begin{abstract}
One of fisheries potential in Bali Strait is tuna fish (Euthynnus sp). Tuna fish (Euthynnus sp) resources is highly influenced by waters productivity which indicated by the chlorophyll-a concentration distribution. The aims of this study are: to find out the concentration spatial of chlorophyll-a distribution in Bali strait, to find out temporal variability of chlorophyll-a and tuna fish (Euthynnus sp) in Bali strait, and to find out the influence of chlorophyll-a concentration distribution to the catch of tuna fish (Euthynnus $s p$ ) in Bali strait. The analysis of the influence of chlorophyll-a concentration distribution to the catch of tuna fish (Euthynnus $s p$ ) in Bali strait uses regression polynomial order 2, correlation, and cross correlation. The influence of chlorophyll-a concentration distribution to the catch of tuna fish (Euthynnus sp) in Bali strait yearly time series climatology amounted to $\mathrm{R}^{2}=0,1624$ or $16,24 \%$, the correlation coefficient values obtained by $\mathrm{r}=0,1889$. Seasonal time series climatology in west season (December February) $R^{2}=0,0707$ or $7,07 \%$, the correlation coefficient values obtained by $r=0,0749$. The transitional season 1 (March - May) $\mathrm{R}^{2}=0,0095$ or $0,95 \%$, the correlation coefficient values obtained by $\mathrm{r}=-0,0092$. The east season (June August) $R^{2}=0,086$ or $8,6 \%$, the correlation coefficient values obtained by $r=-0,2155$. The transitional season 2 (September - November) $R^{2}=0,0482$ or $4,82 \%$. The correlation coefficient values obtained by $r=-0,1805$.
\end{abstract}

Keywords: Bali Strait; tuna fish (Euthynnus sp); chlorophyll-a; aqua MODIS

\begin{abstract}
Abstrak
Salah satu potensi perikanan yang ada di perairan Selat Bali adalah ikan tongkol (Euthynnus sp). Ikan tongkol (Euthynnus sp) dipengaruhi oleh produktivitas perairan yang ditandai dengan sebaran konsentrasi klorofil-a. Tujuan dari penelitian ini, yaitu: mengetahui sebaran spasial konsentrasi klorofil-a di perairan Selat Bali, mengetahui variabilitas temporal klorofil-a dan hasil tangkapan ikan tongkol (Euthynnus sp) di perairan Selat Bali, dan mengetahui pengaruh sebaran konsentrasi klorofil-a terhadap hasil tangkapan ikan tongkol (Euthynnus sp) di perairan Selat Bali. Analisis pengaruh sebaran konsentrasi klorofil-a terhadap hasil tangkapan ikan tongkol (Euthynnus sp) di perairan Selat Bali menggunakan analisis regresi polinomial order 2, korelasi, dan cross correlation. Pengaruh sebaran konsentrasi klorofil-a terhadap hasil tangkapan ikan tongkol (Euthynnus sp) di perairan Selat Bali time series tahunan dengan $\mathrm{R}^{2}=0,1624$ atau $16,24 \%$, nilai koefisien korelasi diperoleh sebesar $\mathrm{r}=0,1889$. Time series musiman pada musim barat (Desember - Februari) dengan $\mathrm{R}^{2}=0,0707$ atau 7,07\%, nilai koefisien korelasi diperoleh sebesar $r=0,0749$. Musim peralihan 1 (Maret - Mei) dengan $\mathrm{R}^{2}=0,0095$ atau 0,95\%, nilai koefisien korelasi diperoleh sebesar $r=-0,0092$. Musim timur (Juni - Agustus) dengan $\mathrm{R}^{2}=0,086$ atau 8,6\%, nilai koefisien korelasi diperoleh sebesar $r=-0,2155$. Musim peralihan 2 (September - November) dengan $R^{2}=0,0482$ atau 4,82\%. Nilai koefisien korelasi diperoleh sebesar $\mathrm{r}=-0,1805$.
\end{abstract}

Kata Kunci: Selat Bali; ikan tongkol (Euthynnus sp); klorofil-a; aqua MODIS 


\section{Pendahuluan}

Perairan Selat Bali terletak di antara Pulau Jawa di sebelah barat dan Pulau Bali di sebelah timur. Perairan Selat Bali berbentuk corong dengan luas sekitar $2.500 \mathrm{~km}^{2}$. Bagian utara merupakan bagian yang sempit dengan lebar sekitar 2,5 km sedangkan lebar di bagian selatan sekitar $55 \mathrm{~km}$. Kedalaman di bagian tengah selat sekitar 300 meter dan semakin dalam di bagian selatan selat yaitu sekitar 1.300 meter (Wujdi, 2013). Sumberdaya perikanan yang terdapat di perairan Selat Bali sangat tinggi dari ikan pelagis kecil hingga pelagis besar seperti ikan tongkol (Euthynnus sp).

Sumberdaya ikan tongkol (Euthynnus sp) adalah salah satu sumberdaya perikanan paling dominan dan bernilai ekonomis tinggi yang merupakan hasil perikanan yang menjadi target tangkapan nelayan. Ikan tongkol (Euthynnus sp) adalah jenis ikan pelagis yang menjadi salah satu komoditas utama ekspor Indonesia (Mujib et al., 2013). Ikan tongkol (Euthynnus sp) sangat dipengaruhi oleh kondisi atau parameter oseanografi perairan seperti klorofil-a.

Klorofil-a merupakan salah satu parameter indikator tingkat kesuburan perairan yang terdapat pada fitoplankton. Konsentrasi klorofil-a biasa disebut dengan pigmen fotosintetik dari fitoplankton. Di perairan laut, indeks klorofil-a dapat dihubungkan dengan produksi ikan atau lebih tepatnya dapat menggambarkan tingkat produktivitas daerah penangkapan ikan (fishing ground) (Safruddin dan Zainuddin, 2008). Dengan adanya sebaran konsentrasi klorofil-a diindikasikan bahwa terdapat banyak ikan pada perairan tersebut. Informasi mengenai kandungan klorofil-a dalam suatu perairan sangat dipengaruhi oleh peran teknologi saat ini. Dengan teknologi yang semakin berkembang maka informasi yang didapat akan semakin banyak dan akurat. Salah satu teknologi yang dapat digunakan untuk mengetahui sebaran konsentrasi klorofil-a pada suatu perairan adalah penginderaan jauh (remote sensing).

Penginderaan jauh (remote sensing) merupakan teknik yang dapat diaplikasikan untuk pengamatan parameter oseanografi perairan seperti konsentrasi klorofil-a. Dengan penginderaan jauh, pemantauan potensi perikanan dapat dilakukan melalui satelit tanpa pemantauan langsung ke lapangan. Salah satu satelit yang dapat mendeteksi kandungan klorofil-a pada perairan adalah satelit Aqua Moderate Resolution Imaging Spectroradiometer (MODIS). Dalam penelitian ini, data satelit Aqua MODIS digunakan untuk menentukan sebaran konsentrasi klorofil-a di perairan Selat Bali.

Tingginya potensi perikanan di perairan Selat Bali, nelayan diharapkan mampu memanfaatkan hasil perikanan dengan optimal. Namun, nelayan sering mengalami permasalahan dalam menentukan waktu penangkapan ikan. Belum maksimalnya pemanfaatan hasil perikanan di Selat Bali diduga karena dalam melakukan penangkapan ikan, nelayan masih menggunakan cara tradisional yaitu dengan pengalaman dan pemanfaatan panca indera sehingga hasil yang didapat belum optimal (wawancara nelayan, 2015).

Melihat tingginya produktivitas di perairan Selat Bali dan permasalahan yang dihadapi nelayan, maka penelitian ini penting untuk dilakukan. Sehingga dengan dianalisisnya sebaran konsentrasi klorofil-a, dapat diketahui pengaruhnya terhadap hasil tangkapan ikan tongkol (Euthynnus sp) di perairan Selat Bali dan memudahkan nelayan dalam menentukan waktu penangkapan ikan secara produktif.

Tujuan dari penelitian ini, yaitu: mengetahui sebaran spasial konsentrasi klorofil-a di perairan Selat Bali, mengetahui variabilitas temporal klorofil-a dan hasil tangkapan ikan tongkol (Euthynnus sp) di perairan Selat, dan mengetahui pengaruh sebaran konsentrasi klorofil-a terhadap hasil tangkapan ikan tongkol (Euthynnus sp) di perairan Selat Bali.

\section{Metode Penelitian}

\subsection{Waktu dan Lokasi Penelitian}

Penelitian ini dilakukan pada bulan Januari 2016 sampai Mei 2016. Penelitian ini meliputi pengambilan data hasil tangkapan ikan tongkol (Euthynnus sp) dan pengolahan data konsentrasi klorofil-a citra satelit Aqua MODIS level 3 periode bulanan. Pengambilan data hasil tangkapan ikan tongkol (Euthynnus sp) diperoleh dari Pelabuhan Perikanan Nusantara (PPN) Pengambengan, Pelabuhan Perikanan Pantai (PPP) Muncar, dan Pangkalan Pendaratan Ikan (PPI) Kuta dan Kuta Selatan. Lokasi penelitian adalah wilayah penangkapan ikan di perairan Selat Bali yang terletak pada titik koordinat $8,16^{\circ} \mathrm{LS}-8,80^{\circ} \mathrm{LS}$ dan 
$114,3^{\circ} \mathrm{BT}-115,2^{\circ} \mathrm{BT}$. Peta lokasi penelitian dapat dilihat pada Gambar 1.

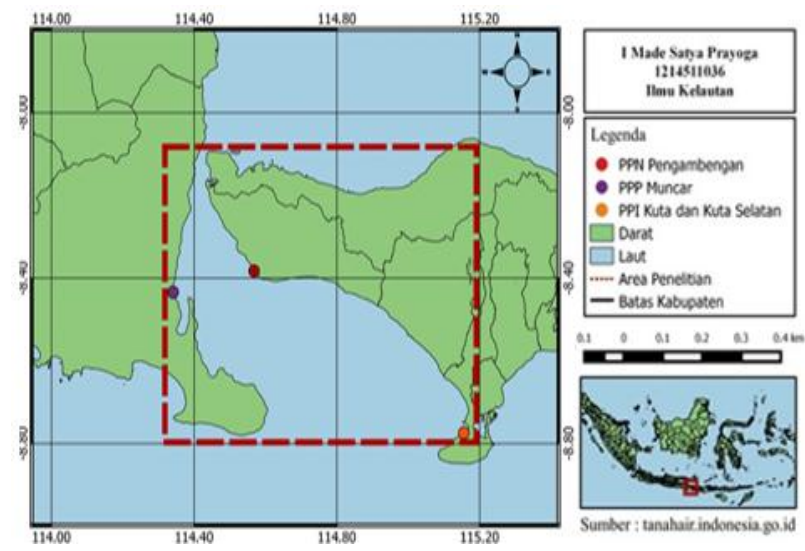

Gambar 1. Peta Lokasi Penelitian

\subsection{Alat dan Data Penelitian}

Penelitian ini menggunakan alat berupa seperangkat komputer yang dilengkapi dengan perangkat lunak yang disajikan pada Tabel 1.

Tabel 1

Alat Penelitian

\begin{tabular}{|c|c|c|}
\hline No & Alat & Fungsi \\
\hline 1 & SAGA_gui & $\begin{array}{l}\text { Mendapatkan } \\
\text { sebaran kilai } \\
\text { klorofil-a dalam bentuk } \\
\text { American Standard Code for } \\
\text { Information Interchange } \\
\text { (ASCII) dan sebaran } \\
\text { spasial konsentrasi } \\
\text { klorofil-a dari citra Aqua } \\
\text { MODIS level3 }\end{array}$ \\
\hline 2 & WinRAR 5.30 & $\begin{array}{l}\text { Mengekstrak citra Aqua } \\
\text { MODIS level } 3 \text { sebaran } \\
\text { konsentrasi klorofil-a }\end{array}$ \\
\hline 3 & QGIS & $\begin{array}{l}\text { Membuat peta lokasi } \\
\text { penelitian }\end{array}$ \\
\hline 4 & $\begin{array}{l}\text { Microsoft Word } \\
2013\end{array}$ & Penulisan penelitian \\
\hline 5 & $\begin{array}{l}\text { Microsoft Excel } \\
2013\end{array}$ & $\begin{array}{l}\text { Membuat grafik time series } \\
\text { dan perhitungan secara } \\
\text { statistik }\end{array}$ \\
\hline
\end{tabular}

Data yang digunakan dalam penelitian ini merupakan data klorofil-a citra satelit aqua MODIS level 3 periode bulanan dan hasil tangkapan ikan tongkol (Euthynnus sp) selama 5 tahun periode Januari 2011 sampai Desember 2015 yang disajikan pada Tabel 2.
Tabel 2

Data Penelitian

\begin{tabular}{|c|c|c|c|}
\hline No & Data & Tempat & Fungsi \\
\hline 1 & Klorofil-a & $\begin{array}{l}\text { Perairan Selat } \\
\text { Bali }\end{array}$ & $\begin{array}{l}\text { Parameter } \\
\text { penelitian }\end{array}$ \\
\hline 2 & $\begin{array}{l}\text { Ikan } \\
\text { tongkol } \\
\text { (Euthynnus } \\
\text { sp) }\end{array}$ & $\begin{array}{l}\text { Pelabuhan } \\
\text { Perikanan } \\
\text { Nusantara } \\
\text { (PPN) } \\
\text { Pengambengan }\end{array}$ & $\begin{array}{l}\text { Mengetahui } \\
\text { total hasil } \\
\text { tangkapan } \\
\text { ikan tongkol } \\
\text { (Euthynnus } s p \text { ) }\end{array}$ \\
\hline 3 & $\begin{array}{l}\text { Ikan } \\
\text { tongkol } \\
\text { (Euthynnus } \\
\text { sp) }\end{array}$ & $\begin{array}{l}\text { Pelabuhan } \\
\text { Perikanan } \\
\text { Pantai (PPP) } \\
\text { Muncar }\end{array}$ & $\begin{array}{l}\text { Mengetahui } \\
\text { total hasil } \\
\text { tangkapan } \\
\text { ikan tongkol } \\
\text { (Euthynnus } s p \text { ) }\end{array}$ \\
\hline 4 & $\begin{array}{l}\text { Ikan } \\
\text { tongkol } \\
\text { (Euthynnus } \\
\text { sp) }\end{array}$ & $\begin{array}{l}\text { Pangkalan } \\
\text { Pendaratan } \\
\text { Ikan (PPI) } \\
\text { Kuta dan Kuta } \\
\text { Selatan }\end{array}$ & $\begin{array}{l}\text { Mengetahui } \\
\text { total hasil } \\
\text { tangkapan } \\
\text { ikan tongkol } \\
\text { (Euthynnus } s p \text { ) }\end{array}$ \\
\hline
\end{tabular}

\subsection{Metode Pengumpulan Data}

\subsubsection{Klorofil-a}

Data konsentrasi klorofil-a diperoleh dari website National Aeronatic Space Agency (NASA) (http://www.oceancolor.gsfc.nasa.gov). Citra yang digunakan adalah citra Aqua MODIS level 3 resolusi $4 \mathrm{~km}$ periode bulanan. Nilai konsentrasi klorofil-a merupakan data bulanan selama 5 tahun periode Januari 2011 sampai Desember 2015.

\subsubsection{Hasil Tangkapan Ikan Tongkol (Euthynnus $s p)$}

Data hasil tangkapan ikan tongkol (Euthynnus sp) diperoleh dari hasil tangkapan yang didaratkan di Pelabuhan Perikanan Nusantara (PPN) Pengambengan, Pelabuhan Perikanan Pantai (PPP) Muncar, dan Pangkalan Pendaratan Ikan (PPI) Kuta dan Kuta Selatan. Hasil tangkapan ikan tongkol (Euthynnus sp) merupakan data bulanan selama 5 tahun periode Januari 2011 sampai Desember 2015.

\subsection{Metode Pengolahan Data}

\subsubsection{Klorofil-a}

Pengolahan data citra satelit Aqua MODIS level 3 untuk mendapatkan nilai konsentrasi klorofil-a melalui beberapa tahapan, yaitu: pengumpulan citra (klorofil-a), pemotongan citra (cropping), dan 
menghitung nilai konsentrasi klorofil-a. Data yang sudah didownload kemudian diekstrak menggunakan perangkat lunak WinRAR 5.30. Pengolahan data dilanjutkan dengan menggunakan perangkat lunak $S A G A \_g u i$.

Pada tahap ini dilakukan pemotongan citra (cropping) berdasarkan wilayah penelitian yaitu perairan Selat Bali dengan titik koordinat $8,16^{\circ} \mathrm{LS}$ $8,80^{\circ} \mathrm{LS}$ dan $114,3^{\circ} \mathrm{BT}$ - 115,2 ${ }^{\circ} \mathrm{BT}$. Hasil dari pemotongan citra dikonversi kedalam bentuk data American Standard Code for Information Interchange (ASCII) yang di dalamnya memiliki variabel bujur, lintang, dan nilai estimasi konsentrasi klorofil-a. Data yang sudah dikonversi kedalam bentuk berupa data ASCII kemudian diolah dengan menggunakan perangkat lunak Microsoft Excel 2013. Data tersebut kemudian ditampilkan dalam bentuk grafik time series 5 tahun periode Januari 2011 sampai Desember 2015.

Untuk menampilkan sebaran spasial klorofil-a menggunakan perangkat lunak SAGA_gui. Citra yang sudah melalui tahap pemotongan (cropping) kembali dibuka pada SAGA_gui dan kemudian diolah sehingga mendapatkan hasil berupa tampilan spasial rata-rata pada setiap bulan yang sama selama 5 tahun periode Januari 2011 sampai Desember 2015. Tampilan dari sebaran spasial konsentrasi klorofil-a berupa tampilan gambar dengan ekstensi ${ }^{*} P N G$.

\subsubsection{Hasil Tangkapan Ikan Tongkol (Euthynnus} $s p)$

Hasil tangkapan ikan tongkol (Euthynnus sp) yang diperoleh dari Pelabuhan Perikanan Nusantara (PPN) Pengambengan, Pelabuhan Perikanan Pantai (PPP) Muncar, dan Pangkalan Pendaratan Ikan (PPI) Kuta dan Kuta Selatan kemudian dijumlahkan pada setiap bulan yang sama. Sehingga didapatkan total hasil tangkapan ikan tongkol (Euthynnus sp) di perairan Selat Bali pada setiap bulan. Data hasil tangkapan ikan tongkol (Euthynnus sp) diolah menggunakan Microsoft Excel 2013 kemudian ditampilkan dalam bentuk grafik time series selama 5 tahun periode Januari 2011 sampai Desember 2015.

\subsection{Analisis Data}

Analisis konsentrasi klorofil-a dan hasil tangkapan ikan tongkol (Euthynnus sp) selama periode Januari 2011 sampai Desember 2015 berdasarkan musim, yaitu: musim barat (Desember - Februari), musim peralihan 1 (Maret - Mei), musim timur (Juni Agustus), dan musim peralihan 2 (September November). Analisis ini dilakukan untuk mengetahui fenomena yang terjadi selama periode penelitian berdasarkan pola musimnya.

\subsubsection{Analisis Sebaran Konsentrasi Klorofil-a}

Sebaran konsentrasi klorofil-a dari citra satelit Aqua MODIS level 3 dianalisis secara spasial dan temporal. Analisis spasial dilakukan secara visual dengan melihat sebaran konsentrasi klorofil-a setiap bulannya di perairan Selat Bali. Analisis spasial konsentrasi klorofil-a berdasarkan penggabungan tiap - tiap bulan yang sama selama 5 tahun periode Januari 2011 sampai Desember 2015 sehingga diketahui sebaran konsentrasi klorofil-a dengan melihat gradasi warna pada citra. Analisis temporal konsentrasi klorofil-a merupakan grafik time series selama 5 tahun periode Januari 2011 sampai Desember 2015 digunakan untuk menginterpretasikan fluktuasi klorofil-a berdasarkan nilai tertinggi dan terendah, serta peningkatan dan penurunannya.

\subsubsection{Analisis Hasil Tangkapan Ikan Tongkol (Euthynnus sp)}

Analisis hasil tangkapan ikan tongkol (Euthynnus $s p$ ) yang didapat dari Pelabuhan Perikanan Nusantara (PPN) Pengambengan, Pelabuhan Perikanan Pantai (PPP) Muncar, dan Pangkalan Pendaratan Ikan (PPI) Kuta dan Kuta Selatan yang sudah diolah dengan menggunakan microsoft excel 2013 ditampilkan dalam bentuk grafik time series selama 5 tahun periode Januari 2011 sampai Desember 2015. Kemudian dianalisis berdasarkan jumlah tertinggi dan terendah, serta peningkatan dan penurunannya.

\subsubsection{Analisis Pengaruh Sebaran Konsentrasi Klorofil-a terhadap Hasil Tangkapan Ikan Tongkol (Euthynnus sp)}

Analisis pengaruh sebaran konsentrasi klorofil-a terhadap hasil tangkapan ikan tongkol (Euthynnus $s p$ ) menggunakan analisis regresi polinomial order 2. Analisis regresi polinomial order 2 digunakan untuk menguji sejauh mana pengaruh variabel independen terhadap variabel dependen. Terdiri dari satu variabel independen $(\mathrm{x})$ dan satu variabel dependen (y). Dalam menganalisis pengaruh sebaran konsentrasi klorofil-a terhadap hasil 
tangkapan ikan tongkol (Euthynnus sp), variabel $x$ merupakan konsentrasi klorofil-a dan variabel y merupakan hasil tangkapan ikan tongkol (Euthynnus sp).

Analisis ini dilakukan berdasarkan time series tahunan, yaitu regresi selama 5 tahun periode Januari 2011 sampai Desember 2015 dan time series musiman, yaitu: regresi musim barat (Desember Februari), musim peralihan 1 (Maret - Mei), musim timur (Juni - Agustus), dan musim peralihan 2 (September - November). Menurut Walpole (1995), regresi polinomial order 2 dapat dinyatakan dalam persamaan 1, yaitu:

$Y=a_{0}+a_{1} x+a_{2} x^{2}$

dimana a adalah konstanta, $\mathrm{x}$ adalah klorofil-a, dan $\mathrm{Y}$ adalah hasil tangkapan ikan tongkol (Euthynnus sp).

Hubungan linier sempurna terjadi antara $x$ dan y bila nilai $\mathrm{r}=+1$ atau -1 . Bila nilai $\mathrm{r}$ mendekati nilai tersebut maka terdapat korelasi yang tinggi antara kedua variabel, sedangkan bila nilai $r$ mendekati nol maka hubungan linear antara nilai $x$ dan $y$ sangat lemah. Analisis korelasi bertujuan mengukur kuat atau tidaknya tingkat keeratan hubungan antara dua variabel (Walpole, 1995). Menurut Walpole (1995), korelasi dinyatakan dalam persamaan 2, yaitu:

$$
r=\frac{\Sigma_{x y}-\frac{\left(\Sigma_{x}\right)\left(\Sigma_{y}\right)}{n}}{\sqrt{\left(\Sigma_{x^{2}}-\frac{\left(\Sigma_{x}\right)^{2}}{n}\right)\left(\Sigma_{y^{2}}-\frac{\left(\Sigma_{y}\right)^{2}}{n}\right)}}
$$

dimana $\mathrm{r}$ adalah koefisien korelasi, $\mathrm{x}$ adalah klorofil-a, y adalah hasil tangkapan ikan tongkol (Euthynnus sp), dan $\mathrm{n}$ adalah jumlah data.

Menurut Sarwono (2006), untuk menginterpretasikan hasil penelitian korelasi disajikan pada Tabel 3, yaitu:

Tabel 3

Tingkat Hubungan Koefisien Korelasi

\begin{tabular}{cc}
\hline Koefisien Korelasi & Tingkat Hubungan \\
\hline 0 & Tidak ada korelasi \\
$0-0,25$ & Korelasi sangat lemah \\
$0,25-0,5$ & Korelasi cukup kuat \\
$0,5-0,75$ & Korelasi kuat \\
$0,75-0,99$ & Korelasi sangat kuat \\
1 & Korelasi sempurna \\
\hline
\end{tabular}

Korelasi dapat menunjukkan tingkat keeratan hubungan antara dua variabel. Namun, tidak selamanya korelasi dua variabel tersebut menunjukkan hubungan yang kuat. Terdapat jeda waktu (time lag) dimana variabel independen dapat mempengaruhi variabel dependen. Sehingga diperlukan time lag analysis menggunakan cross correlation. Cross correlation dinyatakan dalam persamaan 3, yaitu:

$Y_{x y}(l)=\frac{c_{x y}(l)}{s_{x} S_{y}}$

dimana $Y_{x y}(\mathrm{l})$ adalah cross correlation antara $x$ dan $y$ pada waktu ke-1, $C_{x y}$ adalah peragam antara $x$ dan y pada waktu ke-1, Sx adalah standar deviasi $x$ (klorofil-a), $S_{y}$ adalah standar deviasi y (hasil tangkapan ikan tongkol (Euthynnus sp)).

\section{Hasil dan Pembahasan}

\subsection{Sebaran Spasial Konsentrasi Klorofil-a di Perairan Selat Bali}

Sebaran spasial konsentrasi klorofil-a di perairan Selat Bali ditampilkan berdasarkan musim, yaitu: musim barat (Desember - Februari), musim peralihan 1 (Maret - Mei), musim timur (Juni Agustus), dan musim peralihan 2 (September November). Warna ungu menunjukkan sebaran konsentrasi klorofil-a bernilai rendah dan warna merah menunjukkan sebaran konsentrasi klorofil-a bernilai tinggi.

Gambar 2 menunjukkan sebaran spasial konsentrasi klorofil-a rata-rata bulanan musim barat (Desember - Februari) tahun 2011 sampai 2015. Pada musim barat (Desember - Februari) tahun 2011 sampai 2015 perairan Selat Bali memiliki nilai rata-rata konsentrasi klorofil-a bulan Januari sebesar $0,2045 \mathrm{mg} / \mathrm{m}^{3}$, bulan Februari memiliki nilai rata-rata konsentrasi klorofil-a sebesar $0,2255 \mathrm{mg} / \mathrm{m}^{3}$, dan bulan Desember memiliki nilai rata-rata konsentrasi

klorofil-a sebesar $0,2200 \mathrm{mg} / \mathrm{m}^{3}$.

Gambar 3 menunjukkan sebaran spasial konsentrasi klorofil-a rata-rata bulanan musim peralihan 1 (Maret - Mei) tahun 2011 sampai 2015. Pada musim peralihan 1 (Maret - Mei) tahun 2011 sampai 2015 perairan Selat Bali memiliki nilai ratarata konsentrasi klorofil-a bulan Maret sebesar $0,2958 \mathrm{mg} / \mathrm{m}^{3}$, bulan April memiliki nilai rata-rata konsentrasi klorofil-a sebesar $0,5167 \mathrm{mg} / \mathrm{m}^{3}$, dan 
bulan Mei memiliki nilai rata-rata konsentrasi klorofil-a sebesar $0,9566 \mathrm{mg} / \mathrm{m}^{3}$.

Gambar 4 menunjukkan sebaran spasial konsentrasi klorofil-a rata-rata bulanan musim timur (Juni - Agustus) tahun 2011 sampai 2015. Pada musim timur (Juni - Agustus) tahun 2011 sampai 2015 pada perairan Selat Bali memiliki nilai rata-rata konsentrasi klorofil-a bulan Juni sebesar $1,8770 \mathrm{mg} / \mathrm{m}^{3}$, bulan Juli memiliki nilai rata-rata konsentrasi klorofil-a sebesar $1,9260 \mathrm{mg} / \mathrm{m}^{3}$, dan bulan Agustus memiliki nilai rata-rata konsentrasi klorofil-a sebesar 1,9911 mg/m³.

Gambar 5 menunjukkan sebaran spasial konsentrasi klorofil-a rata-rata bulanan musim peralihan 2 (September - November) tahun 2011 sampai 2015. Pada musim peralihan 2 (September -

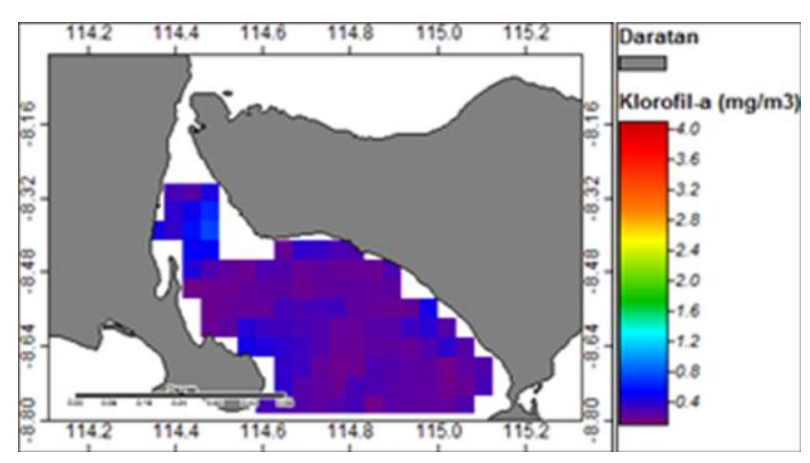

Desember

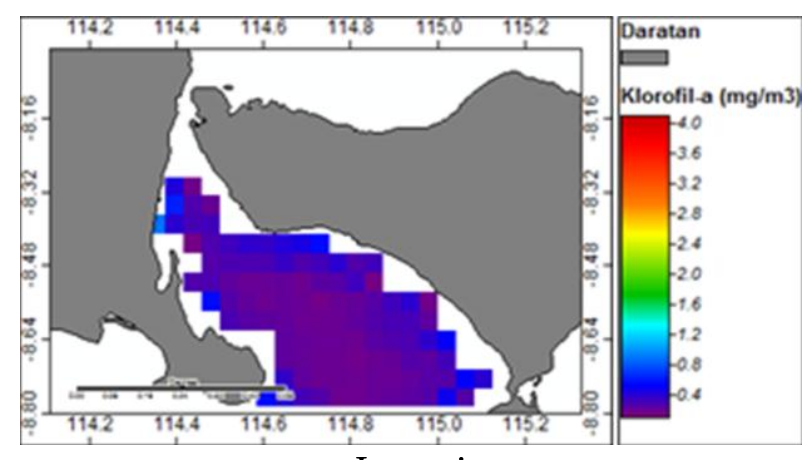

Januari

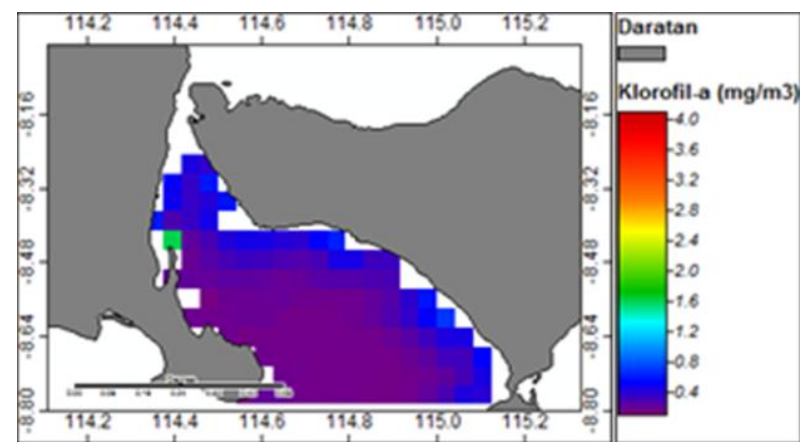

Februari

Gambar 2. Sebaran Spasial Konsentrasi Klorofil-a Ratarata Bulanan Musim Barat (Desember - Februari) Tahun 2011 sampai 2015
November ) tahun 2011 sampai 2015 pada perairan Selat Bali memiliki nilai rata-rata konsentrasi klorofil-a bulan September sebesar 1,5652 mg/m³, bulan Oktober memiliki nilai rata-rata konsentrasi klorofil-a sebesar 2,2693 $\mathrm{mg} / \mathrm{m}^{3}$, dan bulan November memiliki nilai rata-rata konsentrasi klorofil-a sebesar 1,2216 mg/m³.

Sebaran spasial konsentrasi klorofil-a pada musim barat dan musim peralihan 1 merupakan musim dimana konsentrasi klorofil-a memiliki sebaran lebih dominan pada bagian pesisir timur Pulau Jawa dan pesisir barat Pulau Bali. Hal ini diduga terjadi karena tingginya curah hujan yang turun. Tingginya curah hujan menyebabkan banyaknya zat hara yang masuk ke perairan melalui aliran sungai (Putra et al., 2012). Pada
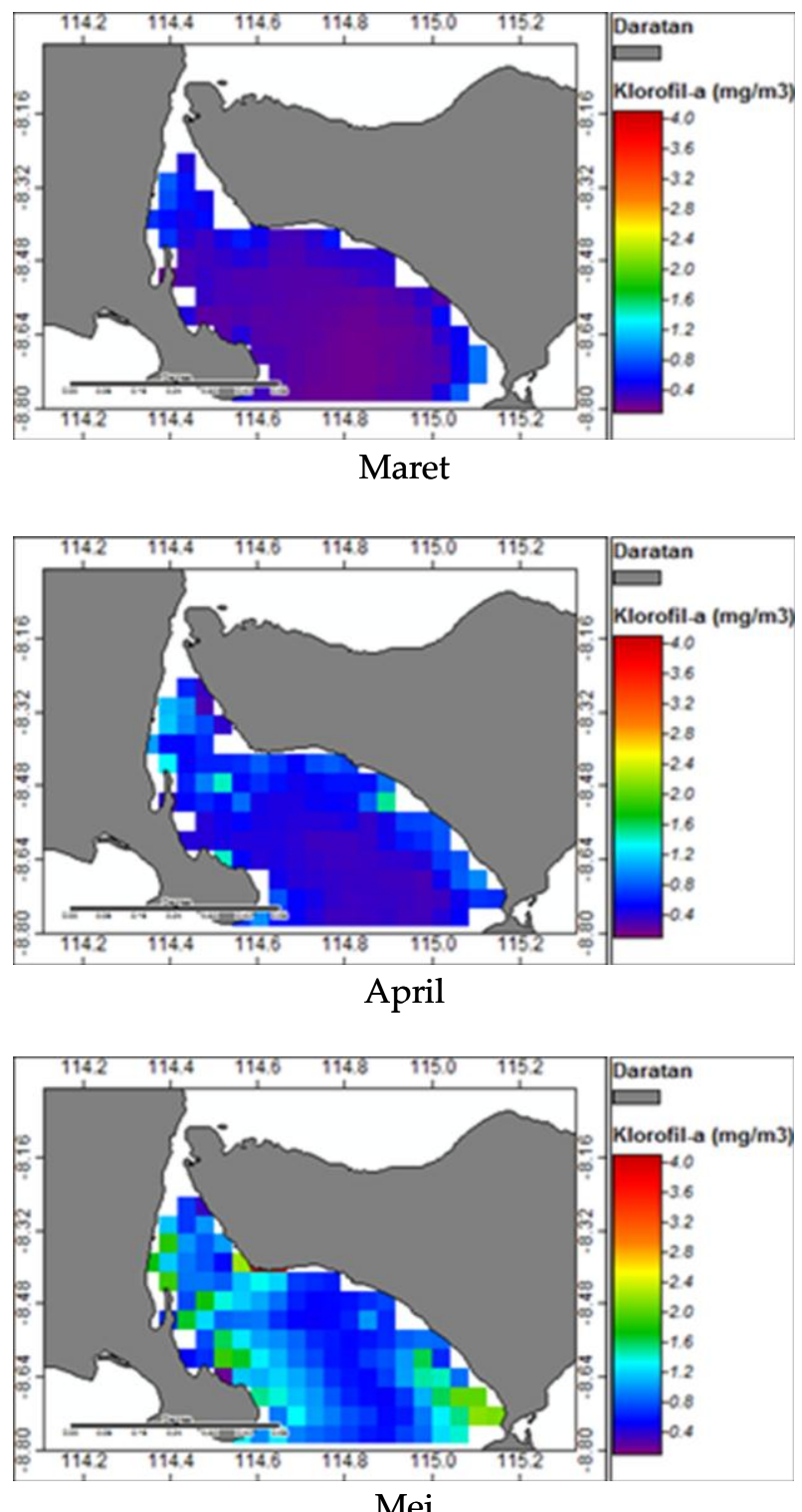

Gambar 3. Sebaran Spasial Konsentrasi Klorofil-a Ratarata Bulanan Musim Peralihan 1 (Maret - Mei) Tahun 2011 sampai 2015 
beberapa tempat masih ditemukan konsentrasi klorofil-a yang cukup tinggi yang disebabkan oleh adanya fenomena upwelling. Fenomena upwelling ditandai dengan penurunan nilai suhu permukaan laut (SPL) dan penin gkatan konsentrasi klorofil-a (Natalia et al., 2015). Upwelling umumnya terjadi pada musim timur. Konsentrasi klorofil-a di perairan Selat Bali mencapai puncak tertinggi pada musim timur (Gambar 4) dengan sebaran konsentrasi klorofil-a terlihat didominasi oleh warna hijau dan mencapai nilai tertinggi yaitu warna merah.

Pada musim timur massa air bergerak dari selatan Selat Bali menuju utara Selat Bali.
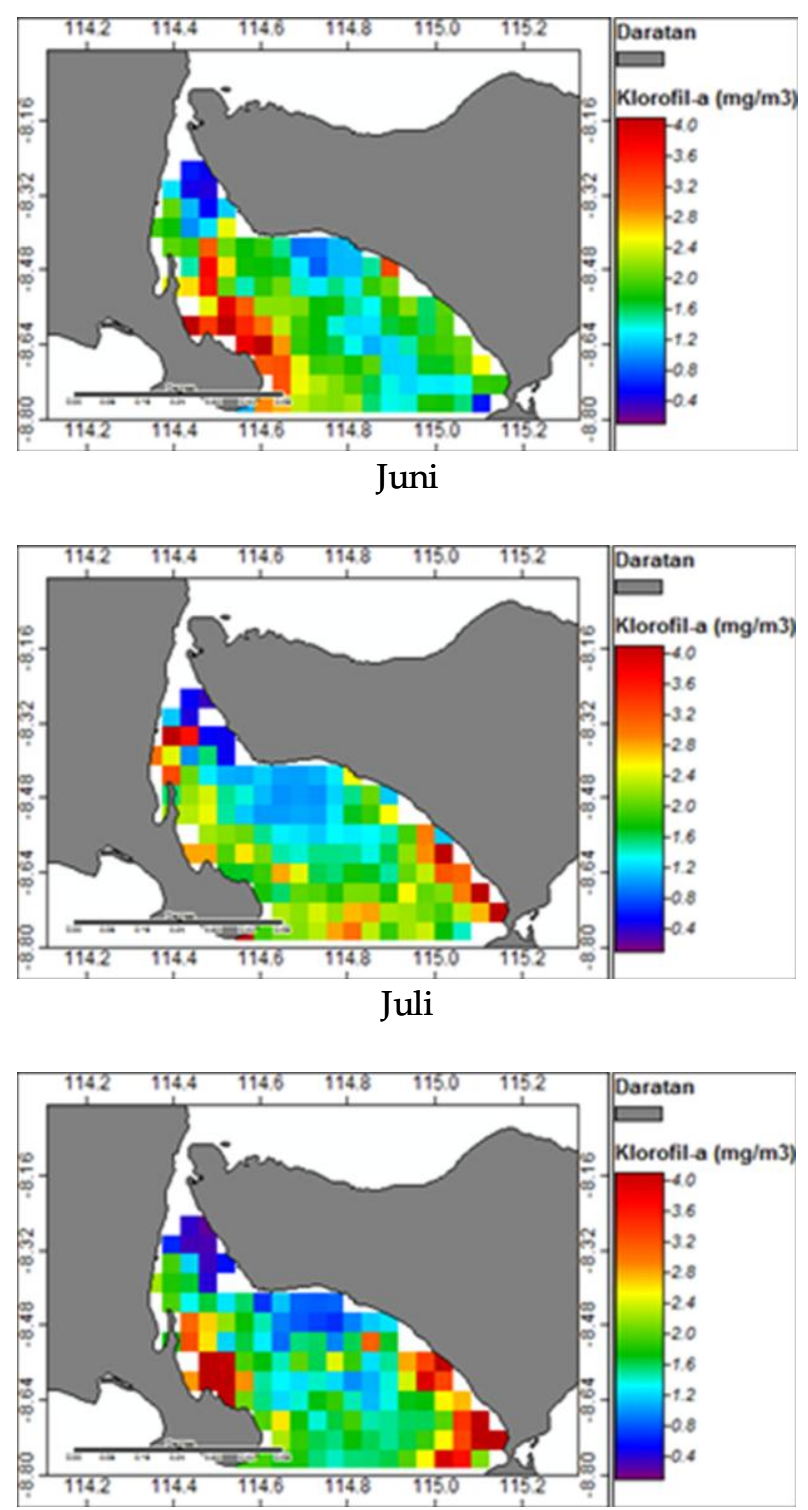

Agustus

Gambar 4. Sebaran Spasial Konsentrasi Klorofil-a Ratarata Bulanan Musim Timur (Juni - Agustus) Tahun 2011 sampai 2015
Pergerakan massa air pada musim timur membuat tingkat kesuburan yang lebih tinggi dibandingkan pada musim barat, dikarenakan massa air hasil upwelling dari Samudera Hindia memiliki unsur hara yang lebih banyak memasuki perairan Selat Bali (Safitri et al., 2014). Selain terjadinya upwelling, musim timur (Juni - Agustus) merupakan musim kemarau dimana sinar matahari yang masuk ke perairan akan lebih banyak dan proses fotosintesis yang dilakukan oleh fitoplankton lebih optimal.

Sebaran konsentrasi klorofil-a pada musim peralihan 2 (September - November) terlihat masih tinggi pada bulan September dan Oktober. Pada bulan November sebaran konsentrasi klorofil-a di
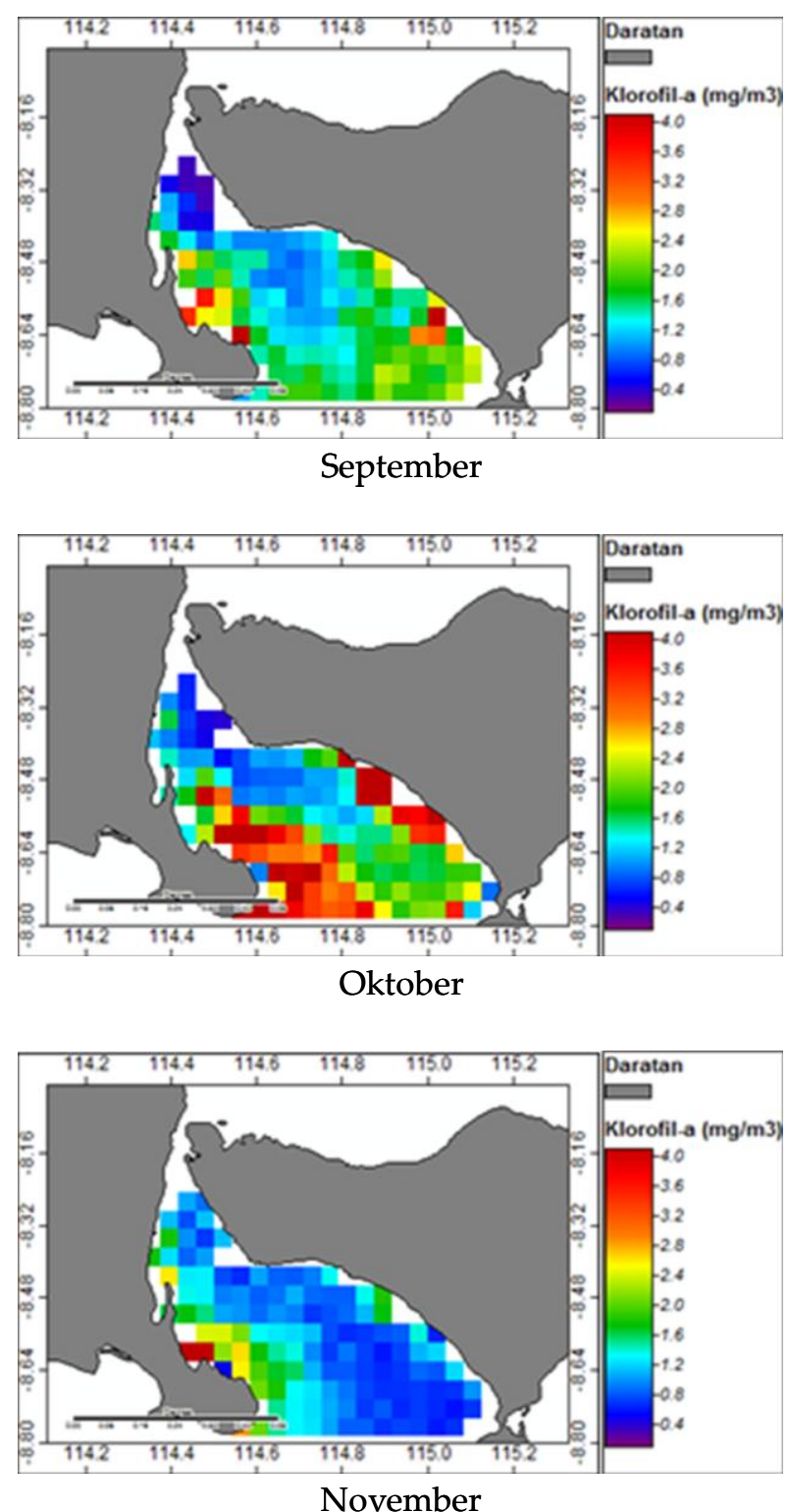

Gambar 5. Sebaran Spasial Konsentrasi Klorofil-a Ratarata Bulanan Musim Peralihan 2 (September November) Tahun 2011 sampai 2015 


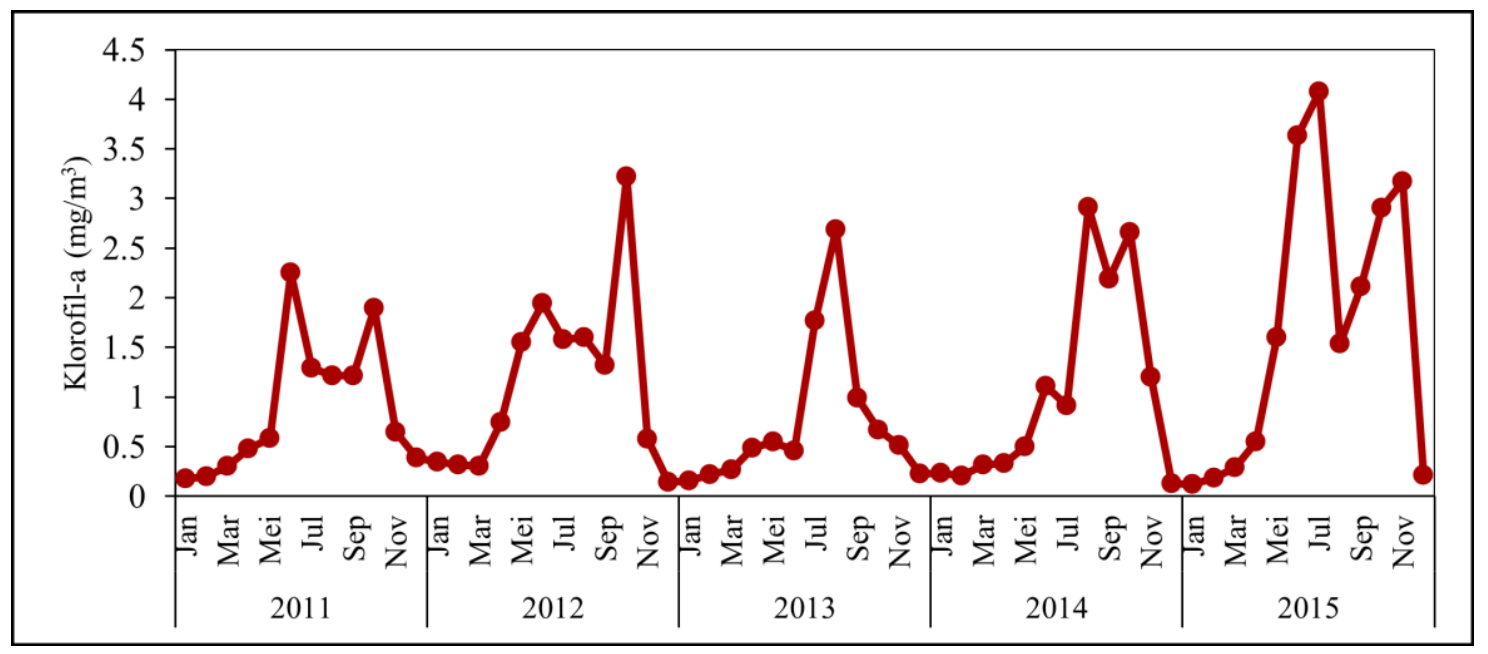

Gambar 6. Fluktuasi Konsentrasi Klorofil-a Tahun 2011 sampai 2015

perairan Selat Bali terlihat mengalami penurunan. Menurunnya intensitas upwelling menyebabkan turunnya kadar nutrien yang berada di lapisan permukaan perairan. Menurunnya kadar nutrien menjadikan perairan menjadi semakin tidak subur, sehingga pertumbuhan fitoplankton berkurang (Hafizhurrahman et al., 2015). Penurunan konsentrasi klorofil-a umumnya terjadi setelah melewati puncak upwelling (Kunarso et al., 2011).

\subsection{Variabilitas Temporal Konsentrasi Klorofil-a di Perairan Selat Bali}

Secara oseanografi, perairan Indonesia termasuk Selat Bali dipengaruhi oleh siklus musim, yaitu: musim timur (Juni - Agustus) dan musim barat (Desember - Februari). Pada musim timur (Juni Agustus) suhu relatif rendah dan konsentrasi klorofil-a meningkat, produktivitas tertinggi terjadi pada musim ini. Sedangkan pada musim barat (Desember - Februari) kandungan klorofil-a mulai mengalami penurunan (Hendiarti et al., 2004).

Gambar 6 menunjukkan fluktuasi konsentrasi klorofil-a tahun 2011 sampai 2015. Pada musim barat (Desember - Februari) tahun 2011 sampai 2015 pada perairan Selat Bali memiliki nilai konsentrasi klorofil-a bulan Januari berkisar 0,1182 - 0,3428 m g/m $\mathrm{m}^{3}$ dengan nilai rata-rata konsentrasi klorofil-a bulan Januari sebesar $0,2045 \mathrm{mg} / \mathrm{m}^{3}$, bulan Februari memiliki nilai konsentrasi klorofila berkisar $0,1844-0,3198 \mathrm{mg} / \mathrm{m}^{3}$ dengan nilai ratarata konsentrasi klorofil-a bulan Februari s ebesar $0,2255 \mathrm{mg} / \mathrm{m}^{3}$, dan bulan Desember memiliki nilai konsentrasi klorofil-a berkisar 0,1312 - 0,3852 $\mathrm{mg} / \mathrm{m}^{3}$ dengan nilai rata-rata konsentrasi klorofil-a bulan Desember sebesar 0,2200 $\mathrm{mg} / \mathrm{m}^{3}$. Nilai ratarata konsentrasi klorofil-a pada musim barat (Desember- Februari) tahun 2011 sampai 2015 sebesar $0,2166 \mathrm{mg} / \mathrm{m}^{3}$.

Pada musim peralihan 1 (Maret - Mei) tahun 2011 sampai 2015 pada perairan Selat Bali memiliki nilai konsentrasi klorofil-a bulan Maret berkisar 0,2654 - 0,3195 $\mathrm{mg} / \mathrm{m}^{3}$ dengan nilai ratarata konsentrasi klorofil-a bulan Maret sebesar $0,2958 \mathrm{mg} / \mathrm{m}^{3}$, bulan April memiliki nilai konsentrasi klorofil-a berkisar 0,3280 - 0,7463 $\mathrm{mg} / \mathrm{m}^{3}$ dengan nilai rata-rata konsentrasi klorofil-a bulan April sebesar 0,5167 mg/m³ dan bulan Mei memiliki nilai konsentrasi klorofil-a berkisar $0,4983-1,6031 \mathrm{mg} / \mathrm{m}^{3}$ dengan nilai rata-rata konsentrasi klorofil-a bulan Mei sebesar 0,9566 $\mathrm{mg} / \mathrm{m}^{3}$. Nilai rata-rata konsentrasi klorofil-a pada musim peralihan 1 (Maret - Mei) tahun 2011 sampai 2015 sebesar 0,5897 mg/m³.

Pada musim timur (Juni - Agustus) tahun 2011 sampai 2015 pada perairan Selat Bali memiliki nilai konsentrasi klorofil-a pada bulan Juni berkisar $0,4554-3,6314 \mathrm{mg} / \mathrm{m}^{3}$ dengan nilai rata-rata konsentrasi klorofil-a bulan Juni sebesar 1,8770 $\mathrm{mg} / \mathrm{m}^{3}$, bulan Juli memiliki nilai konsentrasi Klorofil-a berkisar 0,9141 - 4,0770 mg/m³ dengan nilai rata-rata konsentrasi klorofil-a bulan Juli sebesar 1,9260 mg/m³ dan bulan Agustus memiliki nilai konsentrasi klorofil-a berkisar 1,2171 - 2,9134 $\mathrm{mg} / \mathrm{m}^{3}$ dengan nilai rata-rata konsentrasi klorofil-a bulan Agustus sebesar 1,9911 mg/m³. Nilai ratarata konsentrasi klorofil-a pada musim timur (Juni - Agustus) tahun 2011 sampai 2015 sebesar 1,9317 $\mathrm{mg} / \mathrm{m}^{3}$. 
Pada musim peralihan 2 (September November) tahun 2011 sampai 2015 pada perairan Selat Bali memiliki nilai konsentrasi klorofil-a pada bulan September berkisar 0,9925 - 2,1904 mg/m³ dengan nilai rata-rata konsentrasi klorofil-a bulan September sebesar $1,5652 \mathrm{mg} / \mathrm{m}^{3}$, bulan Oktober memiliki nilai konsentrasi klorofil-a berkisar $0,6672-3,2178 \mathrm{mg} / \mathrm{m}^{3}$ dengan nilai rata-rata konsentrasi klorofil-a bulan Oktober sebesar 2,2693 $\mathrm{mg} / \mathrm{m}^{3}$, dan bulan November memiliki nilai konsentrasi klorofil-a berkisar 0,5125 - 3,1699 $\mathrm{mg} / \mathrm{m}^{3}$ dengan nilai rata-rata konsentrasi klorofil-a bulan November sebesar $1,2216 \mathrm{mg} / \mathrm{m}^{3}$. Nilai ratarata konsentrasi klorofil-a pada musim peralihan 2 (September - November) dari tahun 2011 sebesar $1,6854 \mathrm{mg} / \mathrm{m}^{3}$.

Rata-rata nilai konsentrasi klorofil-a tertinggi terjadi pada musim timur (Juni - Agustus) dengan nilai rata-rata konsentrasi klorofil-a sebesar 1,9317 $\mathrm{mg} / \mathrm{m}^{3}$, kemudian diikuti musim peralihan 2 (September - November) dengan nilai rata-rata konsentrasi klorofil-a sebesar 1,6854 mg/m ${ }^{3}$, musim peralihan 1 (Maret - Mei) dengan nilai ratarata konsentrasi klorofil-a sebesar $0,5897 \mathrm{mg} / \mathrm{m}^{3}$, dan pada musim barat (Desember - Februari) dengan nilai rata-rata konsentrasi klorofil-a sebesar 0,2166 mg/m³.

Konsentrasi Klorofil-a di perairan Selat bali umumnya mencapai puncak tertinggi pada musim timur dan mulai menurun pada musim barat (Arianto et al., 2014). Namun, terjadi penurunan pada beberapa bulan pada saat musim timur seperti Juli dan Agustus tahun 2011, Juli dan Agustus tahun 2012, Juni tahun 2013, Juli tahun 2014, dan Agustus tahun 2015 (Gambar 6) yang diduga karena terjadi fenomena El-Niño Southern Oscillation (ENSO) dan Indian Ocean Dipole (IOD). ENSO dan IOD adalah dua fenomena dominan variasi iklim di Pasifik Tropis dan Samudra Hindia. Kedua fenomena ditunjukkan untuk mempengaruhi kondisi iklim dari beberapa tempat di bumi. Terletak di antara dua area tersebut, Indonesia mempunyai iklim yang terkait dengan ENSO dan IOD (Fadholi, 2013). Ada dua fase saat terjadinya ENSO, yaitu fase panas ( $E l-$ Niño) serta fase dingin ( $L a-N i n ̃ a)$ untuk wilayah Indonesia. Sedangkan terdapat IOD positif dan IOD negatif. IOD positif menyebabkan kekeringan di Indonesia sama halnya dengan El-Niño, sedangkan IOD negatif memiliki sifat yang sama dengan La-Niña, yaitu meningkatkan curah hujan di Indonesia.
Penurunan nilai konsentrasi klorofil-a yang terjadi pada beberapa bulan pada Gambar 6 diduga disebabkan oleh fenomena La-Niña dan IOD negatif. Pada saat kondisi La-Niña, suhu permukaan laut (SPL) di Pasifik Ekuator Timur lebih rendah dari pada kondisi normalnya. Sedangkan SPL di wilayah Indonesia menjadi lebih hangat. Sehingga terjadi peningkatan konveksi dan mengakibatkan massa udara berkumpul di wilayah Indonesia, termasuk massa udara dari Pasifik Ekuator Timur. Fenomena tersebut mengakibatkan curah hujan jauh di atas normal (Fitria dan Pratama, 2013). Menurut Kusriyati (2012) menjelaskan fenomena La-Niña menyebabkan produktivitas perairan di Indonesia menjadi rendah. Sama halnya dengan fenomena IOD negatif. Fenomena IOD negatif menyebabkan peningkatan curah hujan di Indonesia (Hermawan dan Komalaningsih, 2008). Dengan adanya fenomena La-Niña dan IOD negatif menyebabkan penurunan konsentrasi klorofil-a pada beberapa bulan selama periode penelitian Januari 2011 sampai Desember 2015.

Selain adanya fenomena La-Niña dan IOD negatif yang menyebabkan penurunan konsentrasi klorofil-a, diduga ada fenomena lain yang terjadi di perairan Selat Bali. Pada bulan Oktober tahun 2011, Oktober tahun 2012, Agustus tahun 2013, Oktober tahun 2014, November tahun 2015 (Gambar 6) terjadi peningkatan konsentrasi klorofil-a secara signifikan. Diduga adanya fenomena El-Niño dan IOD positif. El-Niño merupakan pemanasan SPL Pasifik Tropis bagian tengah dan timur. Akibatnya aliran massa udara bergerak dari Indonesia menuju ke arah timur yang menyebabkan SPL di Indonesia dan sekitarnya menjadi lebih dingin. Fenomena ElNiño dan IOD positif yang terjadi secara bersamaan menyebabkan durasi upwelling mengalami peningkatan sehingga produktivitas perairan Indonesia menjadi tinggi (Kemili dan Putri, 2012).

\subsection{Variabilitas Temporal Hasil Tangkapan Ikan Tongkol (Euthynnus sp) di Perairan Selat Bali}

Gambar 7 menunjukkan fluktuasi hasil tangkapan ikan tongkol (Euthynnus sp) tahun 2011 sampai 2015. Pada musim barat (Desember- Februari) tahun 2011 sampai 2015 pada perairan Selat Bali memiliki hasil tangkapan ikan tongkol (Euthynnus $s p$ ) bulan Januari berkisar 4.608 - $44.937 \mathrm{~kg}$ dengan rata-rata hasil tangkapan ikan tongkol (Euthynnus 


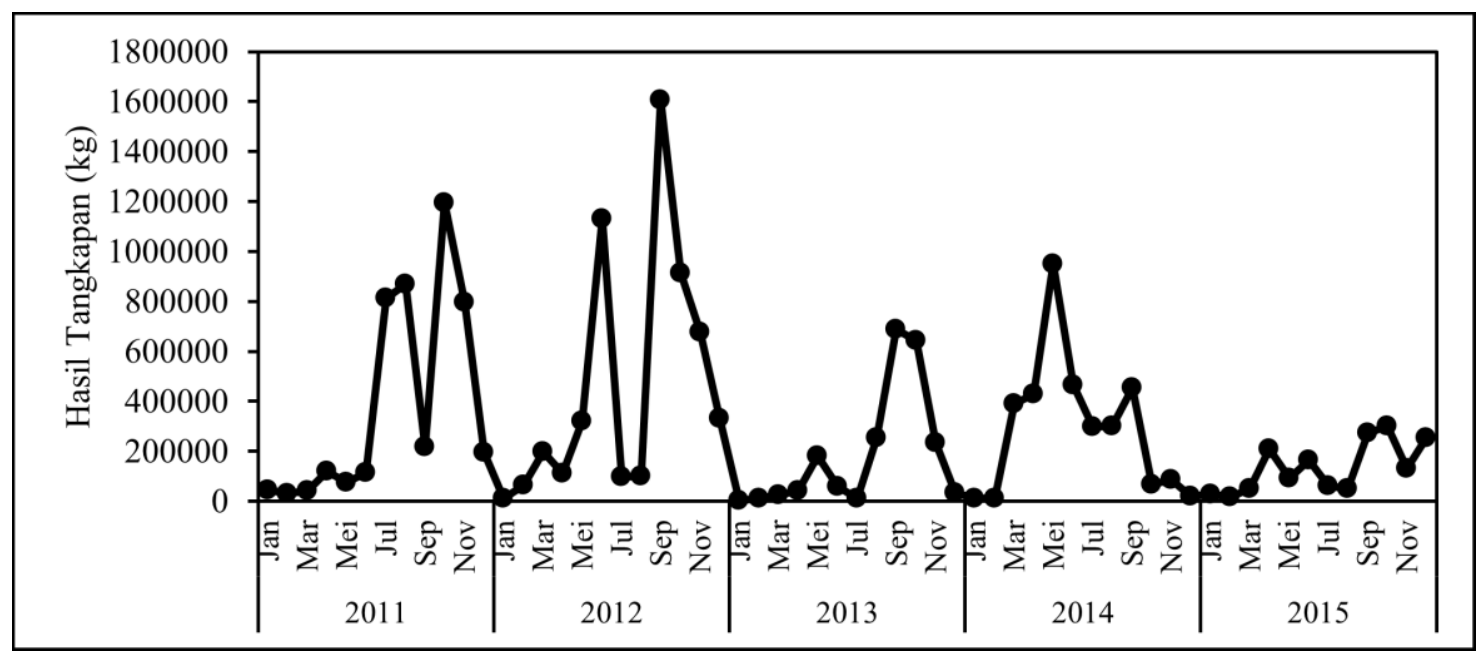

Gambar 7. Fluktuasi Hasil Tangkapan Ikan Tongkol (Euthynnus sp) Tahun 2011 sampai 2015

$s p$ ) bulan Januari sebesar 20.442,7 $\mathrm{kg}$, bulan Februari memiliki hasil tangkapan ikan tongkol (Euthynnus sp) berkisar 10.990 - $63.564 \mathrm{~kg}$ dengan rata-rata hasil tangkapan ikan tongkol (Euthynnus sp) bulan Februari sebesar 27.135,9 kg, dan bulan Desember memiliki has il tangkapan ikan tongkol (Euthynnus sp) berkisar 19.513 - $332.253 \mathrm{~kg}$ dengan rata-rata hasil tangkapan ikan tongkol (Euthynnus $s p$ ) bulan Desember sebesar 167.193,6 kg. Rata-rata hasil tangkapan ikan tongkol (Euthynnus sp) pada musim barat (Desember- Februari) tahun 2011 sampai 2015 sebesar 71.590,7 kg.

Pada musim peralihan 1 (Maret - Mei) dari tahun 2011 sampai 2015 pada perairan Selat Bali memiliki hasil tangkapan ikan tongkol (Euthynnus sp) bulan Maret berkisar 24.598 - 389.323 kg dengan rata-rata hasil tangkapan ikan tongkol (Euthynnus sp) bulan Maret sebesar 140.493 kg, hasil tangkapan ikan tongkol (Euthynnus sp) bulan April berkisar 42.372 - $428.664 \mathrm{~kg}$ dengan rata-rata hasil tangkapan ikan tongkol (Euthynnus $s p$ ) bulan April sebesar $182.424 \mathrm{~kg}$, dan hasil tangkapan ikan tongkol (Euthynnus sp) bulan Mei berkisar 75.189 $948.695 \mathrm{~kg}$ dengan rata-rata hasil tangkapan ikan tongkol (Euthynnus sp) bulan Mei sebesar 323.306,8 kg. Rata-rata hasil tangkapan ikan tongkol (Euthynnus sp) musim peralihan 1 (Maret - Mei) tahun 2011 sampai 2015 sebesar 215.408,2 kg.

Pada musim timur (Juni - Agustus) tahun 2011 sampai 2015 pada perairan Selat Bali memiliki hasil tangkapan ikan tongkol (Euthynnus sp) bulan Juni berkisar 57.817 - $1.129 .578 \mathrm{~kg}$ dengan rata-rata hasil tangkapan ikan tongkol (Euthynnus $s p$ ) bulan Juni sebesar $386.507,4 \mathrm{~kg}$, hasil tangkapan ikan tongkol (Euthynnus sp) bulan Juli berkisar 10.686 -
$812.383 \mathrm{~kg}$ dengan rata-rata hasil tangkapan ikan tongkol (Euthynnus sp) bulan Juli sebesar 256.086,4 $\mathrm{kg}$, dan hasil tangkapan ikan tongkol (Euthynnus sp) bulan Agustus berkisar 51.576 - $870.211 \mathrm{~kg}$ dengan rata-rata hasil tangkapan ikan tongkol (Euthynnus sp) bulan Agustus se besar 315.294,4 kg. Rata-rata hasil tangkapan ikan tongkol (Euthynnus $s p$ ) pada musim timur (Juni - Agustus) tahun 2011 sampai 2015 sebesar 319.296,1 kg.

Pada musim peralihan 2 (September November) dari tahun 2011 sampai 2015 pada perairan Selat Bali memiliki hasil tangkapan ikan tongkol (Euthynnus sp) bulan September berkisar 217.952 - 1.605.215 kg dengan rata-rata hasil tangkapan ikan tongkol (Euthynnus sp) bulan September sebesar $647.831,8 \mathrm{~kg}$, hasil tangkapan ikan tongkol (Euthynnus sp) bulan Oktober berkisar 66.575 - $1.194 .543 \mathrm{~kg}$ dengan rata-rata hasil tangkapan ikan tongkol (Euthynnus sp) bulan Oktober sebesar $624.155 \mathrm{~kg}$, dan hasil tangkapan ikan tongkol (Euthynnus sp) bulan November berkisar 86.559 - $797.723 \mathrm{~kg}$ dengan rata-rata hasil tangkapan ikan tongkol (Euthynnus $s p$ ) bulan November $385.300,4 \mathrm{~kg}$. Rata-rata hasil tangkapan ikan tongkol (Euthynnus sp) pada musim peralihan 2 (September - November) tahun 2011 sampai 2015 sebesar 552. 429,1 kg.

Hasil tangkapan tertinggi terjadi pada musim peralihan 2 (September - November) dengan ratarata hasil tangkapan ikan tongkol (Euthynnus sp) $552.429,1 \mathrm{~kg}$, kemudian pada musim timur (Juni Agustus) dengan rata-rata hasil tangkapan ikan tongkol (Euthynnus sp) sebesar 319.296,1 kg, pada musim peralihan 1 (Maret - Mei) dengan rata-rata hasil tangkapan ikan tongkol (Euthynnus sp) 
$215.408,2 \mathrm{~kg}$, dan pada musim barat (Desember Februari) dengan rata-rata hasil tangkapan ikan tongkol (Euthynnus sp) $71.590 .7 \mathrm{~kg}$. Tingginya hasil tangkapan ikan tongkol (Euthynnus sp) pada musim peralihan 2 (September - November) diduga karena kondisi cuaca kering dan para nelayan dapat melakukan penangkapan dengan optimal. Sedangkan pada musim barat (Desember - Februari) terjadi penurunan hasil tangkapan diduga pada saat musim barat (Desember Februari) cuaca dalam kondisi buruk dengan tingginya curah hujan sehingga menyebabkan nelayan tidak dapat melakukan penangkapan ikan dengan optimal.

Secara umum perairan Selat Bali pada bulan Januari 2011 sampai Desember 2015 memiliki hasil tangkapan ikan tongkol (Euthynnus $s p$ ) sebesar 4.608 - 1.605.215 kg yang menunjukkan hasil tangkapan ikan tongkol (Euthynnus $s p$ ) mengalami peningkatan di setiap bulannya. Namun, pada bulan September tahun 2011, Juli dan Agustus tahun 2012, Juni dan Juli 2013, Juni, Juli, dan Agustus tahun 2014, Mei, Juli, dan Agustus tahun 2015 (Gambar 7) mengalami penurunan hasil tangkapan ikan tongkol (Euthynnus sp). Pada bulan - bulan tersebut merupakan bulan yang sebagian besar termasuk kedalam musim timur (Juni Agustus) dengan kondisi cuaca yang baik dan memiliki intensitas cahaya optimal untuk dilakukannya proses penangkapan ikan.

Rendahnya hasil tangkapan ikan tongkol (Euthynnus sp) pada beberapa bulan tersebut diduga karena adanya fenomena La-Niña dan IOD negatif seperti pada fluktuasi klorofil-a (Gambar 6) dimana terjadi penurunan yang didominasi pada musim timur (Juni - Agustus). Fenomena La-Niña dan IOD negatif menyebabkan intensitas hujan menjadi tinggi dan menyebabkan tutupan awan semakin tebal yang menghalangi sinar matahari masuk ke perairan sehingga mengurangi efektivitas fitoplankton untuk melakukan fotosintesis. Selain berdampak pada rendahnya konsentrasi klorofil-a, fenomena tersebut juga menyebabkan nelayan kesulitan dalam melakukan proses penangkapan ikan karena cuaca yang buruk. Keterbatasan alat tangkap dan sarana prasarana yang dimiliki nelayan semakin menyulitkan untuk dilakukannya proses penangkapan. Sehingga, terjadi penurunan hasil tangkapan ikan tongkol (Euthynnus sp) yang cukup signifikan yang didominasi pada musim timur. Setelah mengalami penurunan pada musim timur hasil tangkapan ikan tongkol (Euthynnus sp) kembali terlihat meningkat pada bulan berikutnya yaitu bulan September. Kemudian kembali menurun pada bulan Oktober sampai Desember karena kembali memasuki musim hujan dengan cuaca yang tidak mendukung untuk melakukan proses penangkapan ikan oleh nelayan.

\subsection{Pengaruh Sebaran Konsentrasi Klorofil-a terhadap Hasil Tangkapan Ikan Tongkol (Euthynnus sp) di Perairan Selat Bali}

Analisis regresi klorofil-a terhadap hasil tangkapan ikan tongkol (Euthynnus sp) dilakukan berdasarkan time series tahunan dan time series musiman. Pada time series musiman, yaitu: musim barat (Desember - Februari), musim peralihan 1 (Maret - Mei), musim timur (Juni - Agustus), dan musim peralihan 2 (September - November).

Gambar 8 menunjukkan regresi konsentrasi klorofil-a terhadap hasil tangkapan ikan tongkol (Euthynnus sp) periode Januari 2011 sampai Desember 2015 di perairan Selat Bali. Analisis regresi polinomial order 2 dengan $Y=-117130 x^{2}+$ $457067 x+47192$ dengan koefisien determinasi $\mathrm{R}^{2}=$ 0,1624 atau $16,24 \%$. Hal tersebut menunjukkan bahwa konsentrasi klorofil-a memberikan pengaruh sebesar $16,24 \%$ terhadap hasil tangkapan ikan tongkol (Euthynnus sp), sedangkan $83,76 \%$ merupakan faktor lain yang mempengaruhi hasil tangkapan ikan tongkol (Euthynnus sp). Nilai koefisien korelasi diperoleh sebesar $r=0,1889$. Nilai korelasi tersebut menunjukkan adanya hubungan linier positif (berbanding lurus) antara klorofil-a dengan hasil tangkapan ikan tongkol (Euthynnus sp). Dimana se makin tinggi nilai konsentrasi klorofil-a diikuti dengan tingginya hasil tangkapan ikan tongkol (Euthynnus sp). Nilai korelasi klorofil-a dengan hasil tangkapan ikan tongkol (Euthynnus sp) termasuk kedalam kategori sangat lemah. Hal tersebut sesuai dengan pernyataan Sarwono (2006) bahwa korelasi yang memiliki rentang nilai $0-0,25$ termasuk kedalam kategori korelasi sangat lemah.

Gambar 9 menunjukkan regresi konsentrasi klorofil-a terhadap hasil tangkapan ikan tongkol (Euthynnus sp) pada musim barat (Desember Februari) tahun 2011 sampai 2015 di perairan Selat Bali Analisis regresi polinomial order 2 dengan $Y=$ $4 \mathrm{E}+06 \mathrm{x}^{2}-2 \mathrm{E}+06 \mathrm{x}+283956$ dengan koefisien determinasi $\mathrm{R}^{2}=0,0707$ atau $7,07 \%$. Hal tersebut menunjukkan bahwa klorofil-a memberikan 


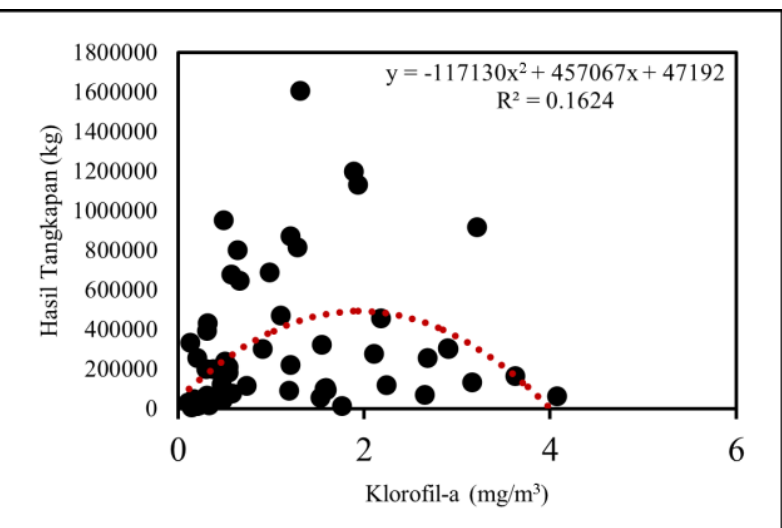

Gambar 8. Grafik Regresi Klorofil-a terhadap Hasil Tangkapan Ikan Tongkol (Euthynnus sp) Tahun 2011 sampai 2015

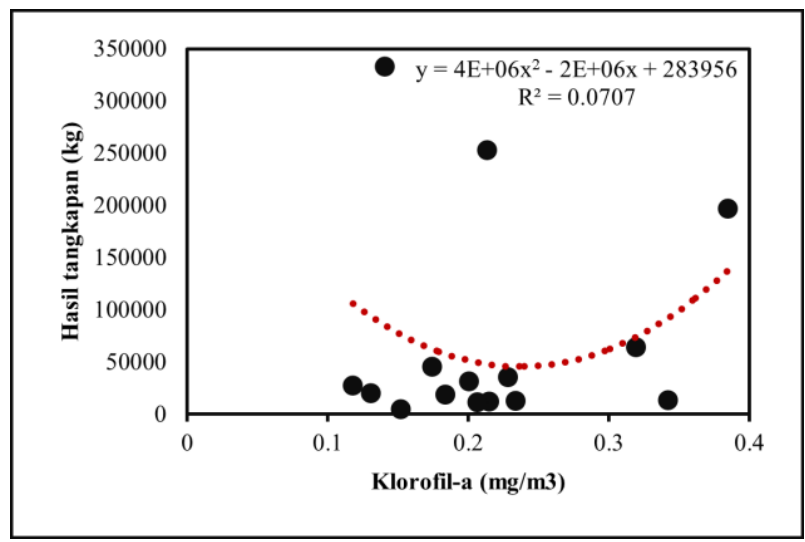

Gambar 9. Grafik Regresi Klorofil-a terhadap Hasil Tangkapan Ikan Tongkol (Euthynnus sp) pada Musim Barat (Desember - Februari) Tahun 2011 sampai 2015

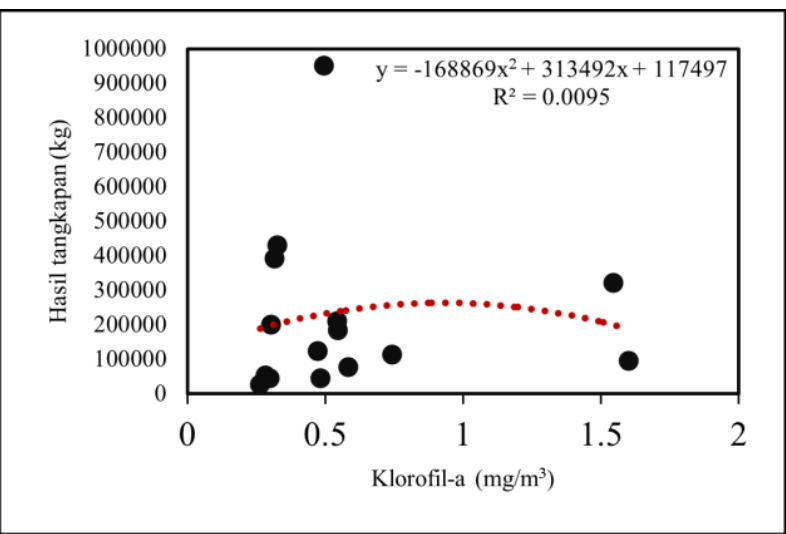

Gambar 10. Grafik Regresi Klorofil-a terhadap Hasil Tangkapan Ikan Tongkol (Euthynnus sp) pada Musim Peralihan 1 (Maret - Mei) Tahun 2011 sampai 2015

pengaruh sebesar 7,07\% terhadap hasil tangkapan ikan tongkol (Euthynnus sp) sedangkan 92,93\% merupakan faktor lain yang mempengaruhi hasil tangkapan ikan tongkol (Euthynnus sp). Nilai

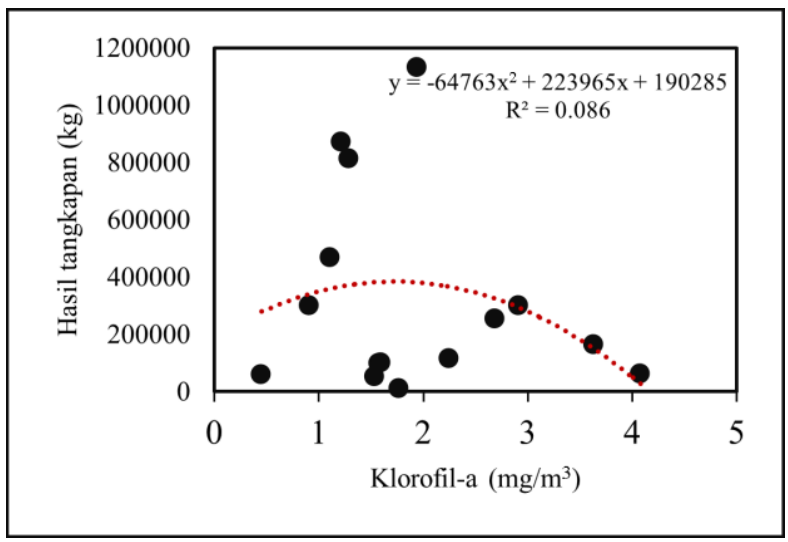

Gambar 11. Grafik Regresi Klorofil-a terhadap Hasil Tangkapan Ikan Tongkol (Euthynnus sp) pada Musim Timur (Juni - Agustus) Tahun 2011 sampai 2015

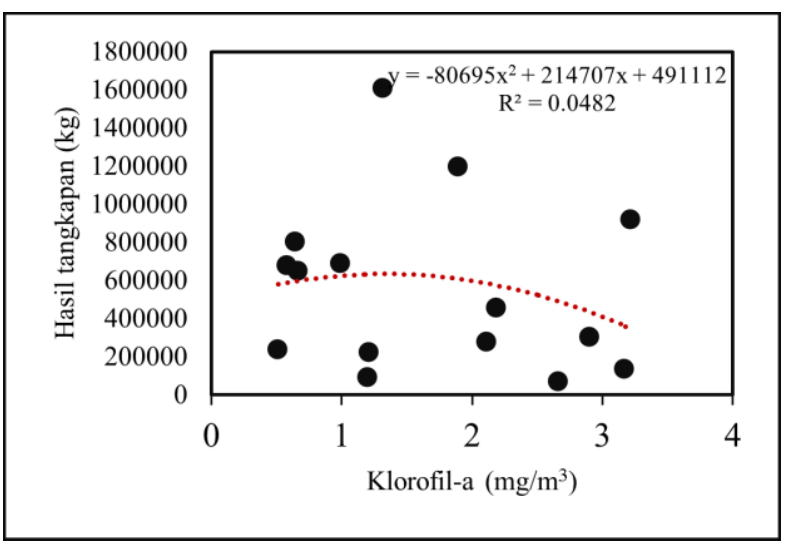

Gambar 12. Grafik Regresi Klorofil-a terhadap Hasil Tangkapan Ikan Tongkol (Euthynnus sp) pada Peralihan 2 (September - November) Tahun 2011 sampai 2015

koefisien korelasi d iperoleh sebesar $r=0,0749$. Nilai korelasi tersebut menunjukkan adanya hubungan linier positif (berbanding lurus) antara klorofil-a dengan hasil tangkapan ikan tongkol (Euthynnus sp). Dimana semakin tinggi nilai konsentrasi klorofil-a diikuti dengan tingginya hasil tangkapan ikan tongkol (Euthynnus sp). Namun, nilai korelasi tersebut termasuk kedalam kategori sangat lemah. Hal tersebut sesuai dengan pernyataan Sarwono (2006) bahwa korelasi yang memiliki rentang nilai $0-0,25$ termasuk kedalam kategori korelasi sangat lemah.

Gambar 10 menunjukkan regresi konsentrasi klorofil-a terhadap hasil tangkapan ikan tongkol (Euthynnus sp) pada musim peralihan 1 (Maret Mei) tahun 2011 sampai 2015 di perairan Selat Bali. Analisis regresi polinomial order 2 dengan $\mathrm{Y}=$ $168869 x^{2}+313492 x+117497$ dengan koefisien determinasi $\mathrm{R}^{2}=0,0095$ atau $0,95 \%$. Hal tersebut menunjukkan bahwa klorofil-a memberikan 
pengaruh sebesar 0,95\% terhadap hasil tangkapan ikan tongkol (Euthynnus sp) sedangkan 99,05\% merupakan faktor lain yang mempengaruhi hasil tangkapan ikan tongkol (Euthynnus sp). Nilai koefisien korelasi diperoleh sebesar $\mathrm{r}=-0,0092$. Nilai korelasi tersebut menunjukkan adanya hubungan linier negatif (berbanding terbalik) antara klorofil-a dengan hasil tangkapan ikan tongkol (Euthynnus sp). Dimana semakin tinggi nilai konsentrasi klorofil-a semakin rendah hasil tangkapan ikan tongkol (Euthynnus $s p$ ) atau semakin rendah nilai konsentrasi klorofil-a semakin tinggi hasil tangkapan ikan tongkol (Euthynnus sp). Nilai korelasi klorofil-a dengan hasil tangkapan ikan tongkol (Euthynnus $s p$ ) termasuk kedalam kategori sangat lemah. Hal tersebut sesuai dengan pernyataan Sarwono (2006) bahwa korelasi yang memiliki rentang nilai 0 - 0,25 termasuk kedalam kategori korelasi sangat lemah.

Gambar 11 menunjukkan regresi konsentrasi klorofil-a terhadap hasil tangkapan ikan tongkol (Euthynnus sp) pada musim timur (Juni - Agustus) tahun 2011 sampai 2015 di perairan Selat Bali. Analisis regresi polinomial order 2 dengan $\mathrm{Y}=$ $64763 x^{2}+223965 x+190285$ dengan koefisien determinasi $\mathrm{R}^{2}=0,086$ atau $8,6 \%$. Hal tersebut menunjukkan bahwa klorofil-a memberikan pengaruh sebesar $8,6 \%$ terhadap hasil tangkapan ikan tongkol (Euthynnus sp) sedangkan 91,4\% merupakan faktor lain yang mempengaruhi hasil tangkapan ikan tongkol (Euthynnus sp). Nilai koefisien korelasi diperoleh sebesar $r=-0,2155$. Nilai korelasi tersebut menunjukkan adanya hubungan linier negatif (berbanding terbalik) antara klorofil-a dengan hasil tangkapan ikan tongkol (Euthynnus sp). Dimana semakin tinggi

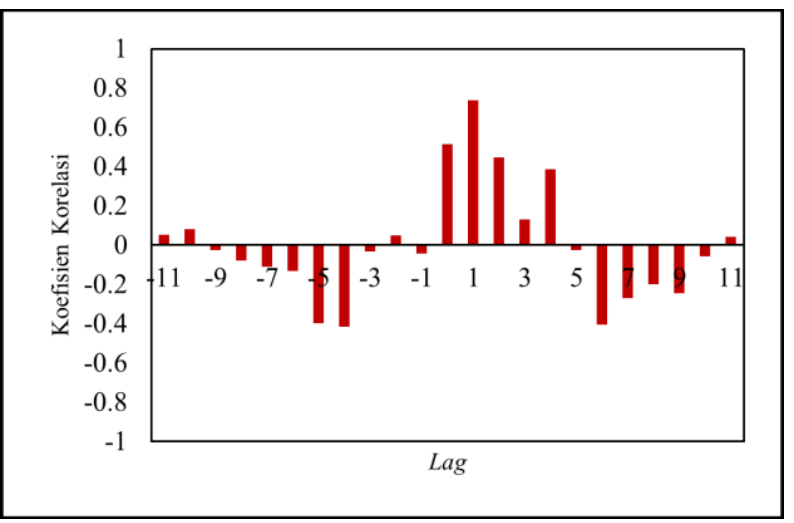

Gambar 13. Grafik Cross Correlation Klorofil-a dengan Hasil Tangkapan Ikan Tongkol (Euthynnus sp) Tahun 2011 nilai konsentrasi klorofil-a semakin rendah hasil tangkapan ikan tongkol (Euthynnus sp) atau semakin rendah nilai konsentrasi klorofil-a semakin tinggi hasil tangkapan ikan tongkol (Euthynnus sp). Nilai korelasi klorofil-a dengan hasil tangkapan ikan tongkol (Euthynnus sp) termasuk kedalam kategori sangat lemah. Hal tersebut sesuai dengan pernyataan Sarwono (2006) bahwa korelasi yang memiliki rentang nilai $0-0,25$ termasuk kedalam kategori korelasi sangat lemah.

Gambar 12 menunjukkan regresi konsentrasi klorofil-a terhadap hasil tangkapan ikan tongkol (Euthynnus $s p$ ) pada musim peralihan 2 (September - November) tahun 2011 sampai 2015 di perairan Selat Bali. Analisis regresi polinomial order 2 dengan $Y=-80695 x^{2}+214707 x+491112$ dengan koefisien determinasi $\mathrm{R}^{2}=0,0482$ atau $4,82 \%$. Hal tersebut menunjukkan bahwa klorofil-a memberikan pengaruh sebesar $4,82 \%$ terhadap hasil tangkapan ikan tongkol (Euthynnus sp) sedangkan $95,18 \%$ merupakan faktor lain yang mempengaruhi hasil tangkapan ikan tongkol (Euthynnus sp). Nilai koefisien korelasi diperoleh sebesar $\mathrm{r}=-0,1805$. Nilai korelasi tersebut menunjukkan adanya hubungan linier negatif (berbanding terbalik) antara klorofil-a dengan hasil tangkap an ikan tongkol (Euthynnus sp). Dimana semakin tinggi nilai konsentrasi klorofil-a semakin rendah hasil tangkapan ikan tongkol (Euthynnus sp) atau semakin rendah nilai konsentrasi klorofil-a semakin tinggi hasil tangkapan ikan tongkol (Euthynnus sp). Nilai korelasi klorofil-a dengan hasil tangkapan ikan tongkol (Euthynnus sp) termasuk kedalam kategori sangat lemah. Hal tersebut sesuai dengan pernyataan Sarwono (2006) bahwa korelasi yang

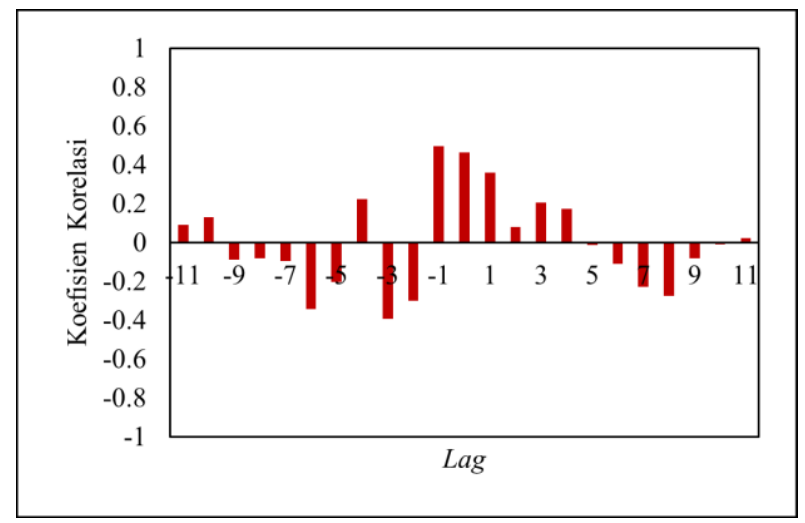

Gambar 14. Grafik Cross Correlation Klorofil-a dengan Hasil Tangkapan Ikan Tongkol (Euthynnus sp) Tahun 2012 


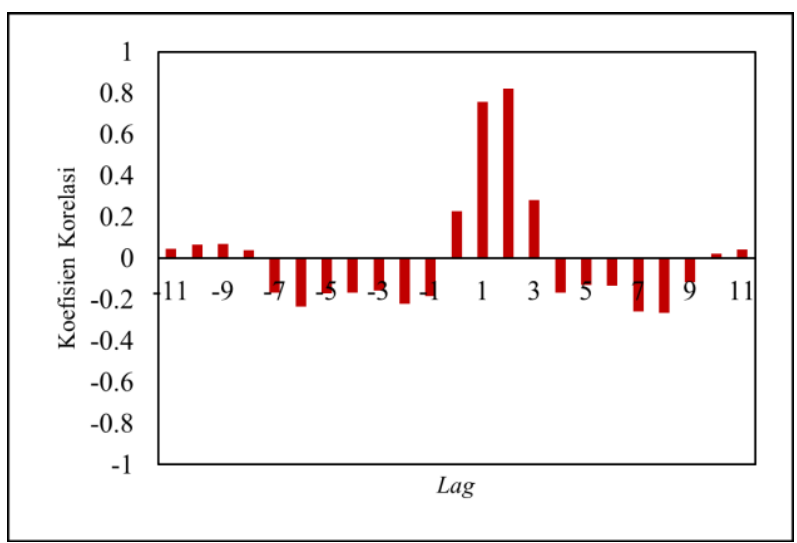

Gambar 15. Grafik Cross Correlation Klorofil-a dengan Hasil Tangkapan Ikan Tongkol (Euthynnus sp) Tahun 2013

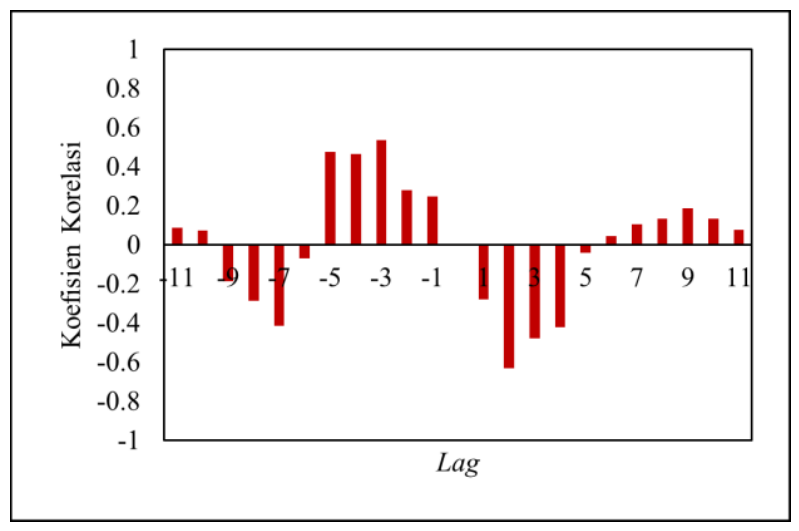

Gambar 16. Grafik Cross Correlation Klorofil-a dengan Hasil Tangkapan Ikan Tongkol (Euthynnus sp) Tahun 2014

memiliki rentang nilai $0-0,25$ termasuk kedalam kategori korelasi sangat lemah.

\subsection{Cross Correlation}

Time series tahunan dan time series musiman baik pada musim barat (Desember - Februari), musim peralihan 1 (Maret - Mei), musim timur (Juni Agustus), dan musim peralihan 2 (September November) tidak memberikan dampak besar pada pengaruh konsentrasi klorofil-a terhadap hasil tangkapan ikan tongkol (Euthynnus sp) di perairan Selat Bali. Menurut Simbolon dan Girsang (2009) konsentrasi klorofil-a sebagai indikasi keberadaan fitoplankton yang terdapat di perairan tidak secara langsung mempengaruhi jumlah ikan tongkol (Euthynnus sp). Diduga adanya jeda waktu (time lag) dalam kondisi tersebut Diperlukan time lag analysis menggunakan cross correlation untuk mengetahui pada jeda waktu (time lag) keberapa

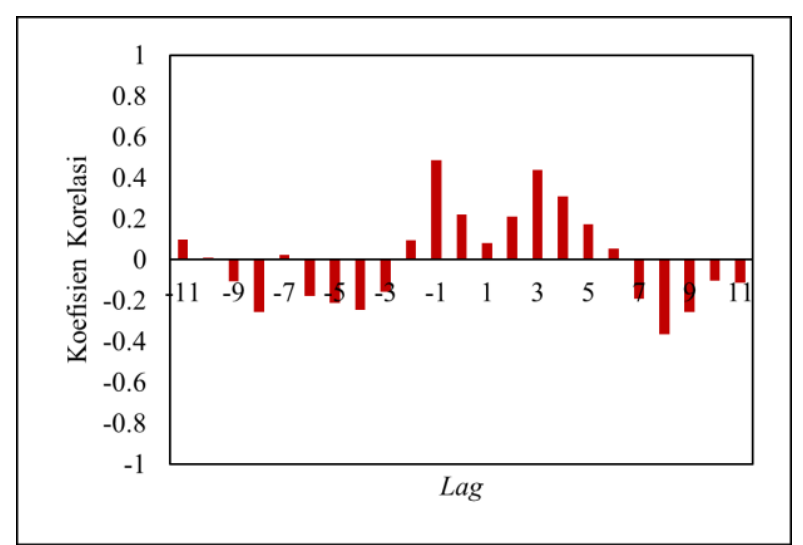

Gambar 17. Grafik Cross Correlation Klorofil-a dengan Hasil Tangkapan Ikan Tongkol (Euthynnus sp) Tahun 2015

klorofil-a dapat mempengaruhi hasil tangkapan ikan tongkol (Euthynnus sp) di perairan Selat Bali.

Gambar 13 menunjukkan grafik cross correlation klorofil-a dengan hasil tangkapan ikan tongkol (Euthynnus sp) tahun 2011. Dari jeda waktu (time lag) terlihat satu bulan ke depan (lag 1) memiliki korelasi tertinggi sebesar 0,7357. Korelasi menunjukkan bahwa klorofil-a mengalami peningkatan yang kemudian diikuti dengan meningkatnya hasil tangkapan ikan tongkol (Euthynnus sp) satu bulan setelah klorofil-a meningkat. Nilai korelasi tersebut menunjukkan adanya hubungan linier positif (berbanding lurus) antara klorofil-a dengan hasil tangkapan ikan tongkol (Euthynnus sp). Dimana semakin tinggi klorofil-a diikuti dengan tingginya hasil tangkapan ikan tongkol (Euthynnus $s p$ ) satu bulan kemudian. Nilai korelasi klorofil-a dengan hasil tangkapan ikan tongkol (Euthynnus sp) termasuk kedalam kategori kuat. Hal tersebut sesuai dengan pernyataan Sarwono (2006) bahwa korelasi yang memiliki rentang nilai 0,5 - 0,75 termasuk kedalam kategori kuat.

Gambar 14 menunjukkan grafik cross correlation klorofil-a dengan hasil tangkapan ikan tongkol (Euthynnus sp) tahun 2012. Pada grafik tidak terlihat korelasi yang signifikan antara klorofil-a dengan hasil tangkapan ikan tongkol (Euthynnus $s p$ ). Dari jeda waktu (time lag) terlihat satu bulan (lag -1) sebelum waktu awal (lag 0) memiliki korelasi tertinggi sebesar 0,4952. Korelasi menunjukkan bahwa hasil tangkapan ikan tongkol (Euthynnus sp) mengalami peningkatan yang kemudian diikuti dengan meningkatnya klorofil-a satu bulan setelah hasil tangkapan ikan tongkol (Euthynnus sp) meningkat. Nilai korelasi tersebut 
menunjukkan adanya hubungan linier positif (berbanding lurus) antara klorofil-a dengan hasil tangkapan ikan tongkol (Euthynnus sp). Dimana semakin tinggi hasil tangkapan ikan tongkol (Euthynnus sp) diikuti dengan tingginya klorofil-a satu bulan kemudian. Nilai korelasi klorofil-a dengan hasil tangkapan ikan tongkol (Euthynnus $s p$ ) termasuk kedalam kategori cukup kuat. Hal tersebut sesuai dengan pernyataan Sarwono (2006) bahwa korelasi yang memiliki rentang nilai 0,25 0,5 termasuk kedalam kategori cukup kuat.

Gambar 15 menunjukkan grafik cross correlation klorofil-a dengan hasil tangkapan ikan tongkol (Euthynnus sp) tahun 2013. Dari jeda waktu (time lag) terlihat satu bu lan ke depan (lag 1) memiliki korelasi sebesar 0,7563 dan dua bulan ke depan (lag 2) memiliki korelasi sebesar 0,8203. Korelasi menunjukkan klorofil-a mengalami peningkatan yang kemudian diikuti dengan meningkatnya hasil tangkapan ikan tongkol (Euthynnus $s p$ ) satu bulan dan dua bulan setelah klorofil-a meningkat. Nilai korelasi menunjukkan adanya hubungan linier positif (berbanding lurus) antara klorofil-a dengan hasil tangkapan ikan tongkol (Euthynnus $s p)$. Dimana semakin tinggi klorofil-a diikuti dengan tingginya hasil tangkapan ikan tongkol (Euthynnus sp) satu bulan dan dua bulan setelah klorofil-a meningkat. Nilai korelasi klorofil-a dengan hasil tangkapan ikan tongkol (Euthynnus $s p$ ) termasuk kedalam kategori sangat kuat. Hal tersebut sesuai dengan pernyataan Sarwono (2006) bahwa korelasi yang memiliki rentang nilai 0,75 0,99 termasuk kedalam kategori sangat kuat.

Gambar 16 menunjukkan grafik cross correlation klorofil-a dengan hasil tangkapan ikan tongkol (Euthynnus sp) tahun 2014. Dari jeda waktu (time lag) terlihat dua bulan ke depan (lag 2) memiliki korelasi sebesar $-0,6325$. Korelasi menunjukkan klorofil-a mengalami peningkatan yang kemudian diikuti dengan menurunnya hasil tangkapan ikan tongkol (Euthynnus sp) dua bulan setelah klorofil-a meningkat. Nilai korelasi menunjukkan adanya hubungan linier negatif (berbanding terbalik) antara klorofil-a dengan hasil tangkapan ikan tongkol (Euthynnus sp). Dimana semakin tinggi klorofil-a maka semakin rendah hasil tangkapan ikan tongkol (Euthynnus sp) dua bulan setelah klorofil-a meningkat. Nilai korelasi klorofil-a dengan hasil tangkapan ikan tongkol (Euthynnus $s p)$ termasuk kedalam kategori kuat. Hal tersebut sesuai dengan pernyataan Sarwono (2006) bahwa korelasi yang memiliki rentang nilai 0,5 - 0,75 termasuk kedalam kategori kuat.

Gambar 17 menunjukkan grafik cross correlation klorofil-a dengan hasil tangkapan ikan tongkol (Euthynnus sp) tahun 2015. Pada grafik tidak terlihat korelasi yang signifikan antara klorofil-a dengan hasil tangkapan ikan tongkol (Euthynnus $s p$ ). Dari jeda waktu (time lag) terlihat korelasi tertinggi yaitu pada satu bulan (lag -1) sebelum waktu awal (lag 0) sebesar 0,4871. Korelasi menunjukkan bahwa hasil tangkapan ikan tongkol (Euthynnus sp) mengalami peningkatan yang kemudian diikuti dengan meningkatnya klorofil-a satu bulan setelah hasil tangkapan ikan tongkol (Euthynnus sp) meningkat. Nilai korelasi tersebut menunj ukkan adanya hubungan linier positif (berbanding lurus) antara klorofil-a dengan hasil tangkapan ikan tongkol (Euthynnus sp). Dimana semaki $\mathrm{n}$ tinggi hasil tangkapan ikan tongkol (Euthynnu $s \quad s p$ ) diikuti dengan tingginya konsentrasi klorofil-a satu bulan kemudian. Nilai korelasi klorofil-a dengan hasil tangkapan ikan tongkol (Euthynnus sp) termasuk kedalam kategori cukup kuat. Hal tersebut sesuai dengan pernyataan Sarwono (2006) bahwa korelasi yang memiliki rentang nilai 0,25 - 0,5 termasuk kedalam kategori cukup kuat.

\section{Simpulan}

Sebaran spasial konsentrasi klorofil-a di perairan Selat Bali pada musim barat (Desember - Februari) dan musim peralihan 1 (Maret - Mei) lebih didominasi pada bagian pesisir timur pulau Jawa dan pesisir barat Pulau Bali. Pada musim timur (Juni - Agustus) dan musim peralihan 2 (September - November) sebaran spasial konsentrasi klorofil-a di perairan Selat Bali tersebar hampir merata pada bagian pesisir timur pulau Jawa dan pesisir barat Pulau Bali hingga laut lepas. Variabilitas temporal konsentrasi klorofil-a tertinggi di perairan Selat Bali terjadi pada musim timur (Juni - Agustus) dengan ratarata konsentrasi korofil-a sebesar $1,9317 \mathrm{mg} / \mathrm{m}^{3}$ dan terendah pada musim barat (Desember Februari) sebesar 0,2166 mg/m $\mathrm{m}^{3}$. Hasil tangkapan ikan tongkol (Euthynnus sp) tertinggi terjadi pada musim peralihan 2 (September - November) dengan rata-rata hasil tangkapan sebesar 552.429,1 $\mathrm{kg}$ dan terendah pada musim barat (Desember Februari) sebesar 71.590,7 kg. 
Pada time series tahunan dan time series musiman klorofil-a memberikan pengaruh yang rendah terhadap hasil tangkapan ikan tongkol (Euthynnus sp). Pada time series tahunan sebesar $16,24 \%$ dan memiliki hubungan linier positif (berbanding lurus). Pada time series musiman, musim barat (Desember - Februari) sebesar 7,7\% dan memiliki hubungan linier positif (berbanding lurus), musim peralihan 1 (Maret - Mei) sebesar $0,95 \%$ dan memiliki hubungan linier negatif (berbanding terbalik), pada musim timur (Juni Agustus) sebesar 8,6\% dan memiliki hubungan linier negatif (berbanding terbalik), dan musim peralihan 2 (September - November) sebesar 4,82\% dan memiliki hubungan linier negatif (berbanding terbalik). Konsentrasi klorofil-a membutuhkan jeda waktu dalam memberikan pengaruh terhadap hasil tangkapan ikan tongkol (Euthynnus $s p$ ) di perairan Selat Bali.

\section{Ucapan Terima Kasih}

Penulis mengucapkan terima kasih kepada Pelabuhan Perikanan Nusantara (PPN) Pengambengan Jembrana, Pelabuhan Perikanan Pantai (PPP) Muncar, dan Pangkalan Pendaratan Ikan (PPI) Kuta dan Kuta Selatan yang telah memberikan dukungan dengan menyediakan data sekunder hasil tangkapan ikan tongkol (Euthynnus sp). Terima kasih kepada NASA(http://www.oceancolor.gsfc.nasa.gov) yang telah menyediakan data klorofil-a dan tentunya Fakultas Kelautan dan Perikanan Universitas Udayana.

\section{Daftar Pustaka}

Arianto, B. Y., Subiyanto, S., \& Hani'ah. (2014). Analisis Hubungan Produktivitas Ikan Lemuru dengan Suhu Permukaan Laut dan Klorofil-a menggunakan Citra Satelit Aqua MODIS. Jurnal Geodesi Undip, 3(4), 158268.

Fadholi, A. (2013). Studi Dampak El Nino dan Indian Ocean Dipole (IOD) terhadap Curah Hujan di Pangkal Pinang. Jurnal Ilmu Lingkungan, 11(1), 43-50.

Fitria, W., \& Pratama, M. S. (2013). Pengaruh Fenomena El Nino 1997 dan La Nina 1999 terhadap Curah Hujan di Biak. Jurnal Meteorologi dan Geofisika, 14(2), 65-74.

Hafizhurrahman, I., Kunarso, \& Suryoputro, A. A. D. (2015). Pengaruh IOD (Indian Ocean Dipole) terhadap Variabilitas Nilai serta Distribusi Suhu Permukaan Laut dan Klorofil-a pada Periode Upwelling di
Perairan Sekitar Bukit Badung Bali. Jurnal Oseanografi, 4(2), 423-433.

Hendiarti, N., Herbert, S., \& Thomas, O. (2004). Investigation of Different Coastal Processes In Indonesian Waters Using Seawifs Data. Deep-Sea Research II, 51, 85-97.

Hermawan, E., \& Komalaningsih, K. (2008). Karakteristik Indian Ocean Dipole Mode di Samudera Hindia Hubungannya dengan Perilaku Curah Hujan di Kawasan Sumatera Barat Berbasis Analisis Mother Wavelet. Jurnal Sains Dirgantara, 5(2), 109-129.

Kemili, P., \& Putri, M. R. (2012). Pengaruh Durasi dan Intensitas Upwelling Berdasarkan Anomali Suhu Permukaan Laut Terhadap Variabilitas Produktivitas Primer di Perairan Indonesia. Jurnal Ilmu dan Teknologi Kelautan Tropis, 4(1), 66-79.

Kunarso, K., Hadi, S., Ningsih, N. S., \& Baskoro, M. S. (2012). Variabilitas suhu dan klorofil-a di daerah upwelling pada variasi kejadian ENSO dan IOD di perairan selatan Jawa sampai Timor. ILMU KELAUTAN: Indonesian Journal of Marine Sciences, 16(3), 171-180.

Kusriyati. (2012). Kajian ENSO, Hubungannya dengan Suhu Permukaan Laut dan Konsentrasi Klorofil-a di Teluk Bone. Tesis. Yogyakarta, Indonesia: Program Studi Ilmu Lingkungan, Universitas Gadjah Mada.

Mujib, Z., Boesno, H., \& Fitri, A. D. P. (2013). Pemetaan Sebaran Ikan Tongkol (Euthynnus sp.) dengan Data Klorofil-a Citra MODIS pada Alat Tangkap Payang (Danish-seine) di Perairan Teluk Pelabuhanratu, Sukabumi, Jawa Barat. Journal of Fisheries Resources Utilization Management and Technology, 2(2), 150-160.

Natalia, E. H., Kunarso, \& Rifai, A. (2015). Variabilitas Suhu Permukaan Laut dan Klorofil-a Kaitannya dengan El Nino Southern Oscillation (ENSO) dan Indian Ocean Dipole (IOD) pada Periode Upwelling 2010-2014 di Lautan Hindia (Perairan Cilacap). Jurnal Oseanografi, 4(4), 661-669.

Putra, E., Lumban-Gaol, J., \& Siregar, V. P. (2012). Hubungan Konsentrasi Klorofil-a dan Suhu Permukaan Laut dengan Hasil Tangkapan Ikan Pelagis Utama di Perairan Laut Jawa dari Citra Satelit MODIS. Jurnal Teknologi Perikanan dan Kelautan, 3(1), $1-10$.

Safitri, W., Hariadi, \& Sugiyanto, D. N. (2014). Analisa Hubungan Nitrat terhadap Distribusi Klorofil-a di Perairan Selatan Selat Bali pada Musim Timur. Jurnal Oseanografi, 3(1), 7-15.

Safruddin, \& Zainuddin, M. (2008). Prediksi Daerah Penangkapan Ikan Cakalang Berdasarkan Kondisi Oseanografi di Perairan Kabupaten Takalar dan Sekitarnya. Jurnal Sains dan Teknologi, 8(2), 158-162.

Sarwono, J. (2006). Metode Penelitian Kuantitatif dan Kualitatif. Yogyakarta, Indonesia: Graha Ilmu. 
Simbolon, D., \& Girsang, H. S. (2009). Hubungan antara Kandungan Klorofil-a dengan Hasil Tangkapan Ikan Tongkol di Daerah Penangkapan Ikan Perairan Pelabuhanratu. Jurnal penelitian perikanan Indonesia, 15(4), 297-305.
Walpole, R. E. (1995). Pengantar Statistik. Jakarta, Indonesia: Gramedia Pustaka Utama.

Wujdi, A. (2013). Beberapa Parameter Populasi Ikan Lemuru (Sardinella lemuru) di Perairan Selat Bali. Widyariset, 16(2), 211-218.

(C) 2017 by the authors; licensee Udayana University, Indonesia. This article is an open access article distributed under the terms and conditions of the Creative Commons Attribution license (http://creativecommons.org/licenses/by/3.0/). 